\title{
Modelling of biospheric $\mathrm{CO}_{2}$ gross fluxes via oxygen isotopes in a spruce forest canopy: $\mathrm{a}^{222} \mathrm{Rn}$ calibrated box model approach
}

\author{
By UWE LANGENDÖRFER ${ }^{1}$, MATTHIAS CUNTZ ${ }^{1,2}$, PHILIPPE CIAIS ${ }^{2}$, PHILIPPE PEYLIN ${ }^{2,3}$, \\ THIERRY BARIAC ${ }^{3}$, IRENA MILYUKOVA ${ }^{4}$, OLAF KOLLE ${ }^{5}$, TOBIAS NAEGLER ${ }^{1}$ and \\ INGEBORG LEVIN ${ }^{1 *}$, ${ }^{1}$ Institut für Umweltphysik, Universität Heidelberg (UHEI-IUP), Im Neuenheimer \\ Feld 229, 69120 Heidelberg, Germany; ${ }^{2}$ Laboratoire des Sciences du Climat et de l'Environnement (LSCE), \\ Commisariat à l' Energie Atomique, L'Orme des Merisiers, Bât 709, 91191 Gif sur Yvette, France; ${ }^{3}$ Laboratoire \\ de Biogéochimie Isotopique (INRA), Université Pierre et Marie Curie, 75005 Paris, France; ${ }^{4}$ Servertzov In- \\ stitute of Evolutionary and Ecological Problems (IPEE), Suckachev Laboratory for Biogeocenology, Rus- \\ sian Academy of Sciences, Leninskii pr. 33, 117071 Moscow, Russia; ${ }^{5}$ Max-Planck-Institut für Biogeochemie \\ (MPI-BGC), Postfach 100 164, 07701 Jena, Germany
}

(Manuscript received 9 July 2001; in final form 18 June 2002)

\begin{abstract}
One-dimensional box model estimates of biospheric $\mathrm{CO}_{2}$ gross fluxes are presented. The simulations are based on a set of measurements performed during the EUROSIBERIAN CARBONFLUX intensive campaign between 27 July and 1 August 1999 in a natural Picea abies forest in Russia. $\mathrm{CO}_{2}$ mixing ratios and stable isotope ratios of $\mathrm{CO}_{2}$ were measured on flask samples taken in two heights within the canopy. Simultaneously, soil and leaf samples were collected and analysed to derive the ${ }^{18} \mathrm{O} /{ }^{16} \mathrm{O}$ ratio of the respective water reservoirs and the ${ }^{13} \mathrm{C} /{ }^{12} \mathrm{C}$ ratio of the leaf tissue. The main objective of this project was to investigate biospheric gas exchange with soil and vegetation, and thereby take advantage of the potential of the ${ }^{18} \mathrm{O} /{ }^{16} \mathrm{O}$ ratio in atmospheric $\mathrm{CO}_{2}$. Via exchange of oxygen isotopes with associated liquid water reservoirs, leaf $\mathrm{CO}_{2}$ assimilation fluxes generally enrich while soil $\mathrm{CO}_{2}$ respiration fluxes generally deplete the ${ }^{18} \mathrm{O} /{ }^{16} \mathrm{O}$ ratio of atmospheric $\mathrm{CO}_{2}$. In the model, we parameterised intracanopy transport by exploiting soil-borne ${ }^{222} \mathrm{Rn}$ as a tracer for turbulent transport. Our model approach showed that, using oxygen isotopes, the net ecosystem $\mathrm{CO}_{2}$ flux can be separated into assimilation and respiration yielding fluxes comparable with those derived by other methods. However, partitioning is highly sensitive to the respective discrimination factors, and therefore also on the parameterisation of internal leaf $\mathrm{CO}_{2}$ concentrations and gradients.
\end{abstract}

\section{Introduction}

The recent atmospheric budget of carbon dioxide can be balanced only by postulating a significant sink of $\mathrm{CO}_{2}$ in the terrestrial biosphere (Schimel et al., 1996). The characterisation and localisation of this biospheric sink is, however, still a matter of debate

*Corresponding author. e-mail: ingeborg.levin@iup.uni-heidelberg.de
(Ciais et al., 1995a,b; Francey et al.,1995; Fan et al., 1998; Bousquet et al., 1999). Recently, the ${ }^{18} \mathrm{O} /{ }^{16} \mathrm{O}$ ratio of atmospheric $\mathrm{CO}_{2}$ has evoked scientific attention within the global carbon cycle research because of its unique potential to provide additional information on carbon exchange between the atmosphere and the terrestrial biosphere, i.e. on the gross carbon fluxes of vegetated areas. Biospheric gas exchange with soil and vegetation modifies the pattern of the ${ }^{18} \mathrm{O} /{ }^{16} \mathrm{O}$ ratio in atmospheric $\mathrm{CO}_{2}$ via exchange of oxygen isotopes with associated liquid water reservoirs 
(Francey and Tans, 1987; Farquhar et al., 1993; Ciais et al., 1997a,b). As leaf $\mathrm{CO}_{2}$ generally enriches and soil $\mathrm{CO}_{2}$ respiration fluxes generally deplete the ${ }^{18} \mathrm{O} /{ }^{16} \mathrm{O}$ ratio of atmospheric $\mathrm{CO}_{2}$, the oxygen isotope composition of $\mathrm{CO}_{2}$ carries unique information on the gross fluxes of $\mathrm{CO}_{2}$ exchanged by land ecosystems (photosynthesis, ecosystem respiration), rather than on the net fluxes which are constrained by $\mathrm{CO}_{2}$ and ${ }^{13} \mathrm{C}$.

There have been several studies on a local scale which investigated the isotopic interaction of $\mathrm{CO}_{2}$ and $\mathrm{H}_{2} \mathrm{O}$. Main objective was to study the potential of ${ }^{18} \mathrm{O}$ in $\mathrm{CO}_{2}$ and water, to eventually differentiate between assimilation and respiration fluxes (e.g. Yakir and Wang, 1996; Flanagan et al., 1997). Yakir and Wang (1996) estimated separately $\mathrm{CO}_{2}$ uptake and respiration fluxes from small vertical gradients in atmospheric $\mathrm{CO}_{2}$ and stable isotopes over crop fields. To derive the net fluxes they calculated eddy turbulent exchange from wind speed profiles and surface characteristics. Flanagan et al. (1997) measured plant stem and leaf water in three major forest types to calculate plant discrimination. They estimated the impact of respiration and assimilation fluxes on ecosystem air by coupling ${ }^{18} \mathrm{O}$ discrimination with concurrently measured eddy covariance net $\mathrm{CO}_{2}$ fluxes, whereby respiration fluxes where estimated from eddy covariance nighttime measurements. Here, we present an approach that closes the mass balances for both $\mathrm{CO}_{2}$ and the $\delta^{18} \mathrm{O}$ $\mathrm{CO}_{2}$ by coupling biospheric exchange fluxes, vertical transport fluxes within the canopy and canopy/CBL (convective boundary layer) exchange fluxes. Our objective is to solve the system of mass balance equations for the assimilation and ecosystem respiration fluxes separately by using measured isotope ratios in canopy air, soil and leaves. The overall net $\mathrm{CO}_{2} \mathrm{ex}-$ change (NEE) determined via eddy covariance measurements at the top of the canopy (Milyukova et al., 2002) is used as an input of the model which apportions the gross fluxes. To parameterise the intra-canopy turbulent transport we use the soil-borne atmospheric ${ }^{222} \mathrm{Rn}$ activity as a tracer.

\section{Experimental}

\subsection{Area of investigation}

The measurements were performed during an intensive campaign from 27 July to 1 August 1999 in a natural Picea abies forest in the 'Central Forest Reserve' (CFR) at Fyodorovskoe $\left(56^{\circ} 27^{\prime} \mathrm{N}, 32^{\circ} 55^{\prime} \mathrm{E}\right)$ near Neli- dovo. The 'Central Forest Reserve' is located about $300 \mathrm{~km}$ north-west of Moscow in the central part of European Russia, the south-west part of the Valdai upland of the Russian Plain. The forest type at the measurement location is dominated by $36 \%$ birch and $20 \%$ spruce stocks; $30 \%$ consists of a mixture of birch and spruce, $12 \%$ is pine and the residual forest consists of alder and deciduous trees (Daniil Kozlov, personal communication). Vegetation is represented by southern taiga biota that penetrated into broad-leaved forests of the central part of the Russian Plain. The pattern and characteristics of vegetation cover are primarily controlled by its location in the watershed. The forest understory is dominated by blueberry and sphagnum moss vegetation. The soil profile is rich in humus in the top $50 \mathrm{~cm}$ followed by a course loamy soil to a depth of about $1 \mathrm{~m}$. Bogs cover in total $4 \%$ of the CFR area. The age of the spruce trees is $181 \pm 35 \mathrm{yr}$ with an average height of about $27 \mathrm{~m}$ (LAI 4.3), the understory small shrub and moss layers are dominated by Vaccinium myrtillus (bilberry, a relative of blueberry) and Sphagnum girgensohnii, respectively, hereafter referred to as "blueberries" and "mosses". The predominant native wood species (49\% of the total CFR area) is spruce (Picea abies L.) that was not actively used by man before 1931 and after 1960 .

\subsection{Sampling}

Ambient air flask sampling for analysis of $\mathrm{CO}_{2}$ mixing ratio and stable isotope ratios was installed at the forest tower where the air was sampled from 1.8 and $26.3 \mathrm{~m}$ height above ground within and slightly above the canopy (tubing: dekabon furon 1300; pump: KNF Neuberger PM 16029, 24 V). Two preconditioned glass flasks (1.2 L volume each) were flushed with atmospheric air at a flow rate of $2 \mathrm{~L} \mathrm{~min}^{-1}$ for about $30 \mathrm{~min}$ and finally pressurised to 1 bar above ambient pressure. Condensation of water vapour in the flask can lead to oxygen isotope exchange of the sampled $\mathrm{CO}_{2}$ with the liquid water (Gemery et al., 1996). Therefore, a cryo-cooling system (a U-shaped glass tube filled with glass bulbs, length about $60 \mathrm{~cm}$, diameter about $2 \mathrm{~cm}$, also used for water vapour sampling) prior to a chemical drying column (magnesium perchlorate) was implemented in the $26.3 \mathrm{~m}$ and $1.8 \mathrm{~m}$ sampling lines and reduced the vapour pressure of the air streams to a dewpoint of less than $-40^{\circ} \mathrm{C}$. During the whole intensive campaign, a time resolution of $2 \mathrm{~h}$ for flask sampling was maintained. These samples were analysed in the Heidelberg laboratory by GC-FID 
(gas chromatography - flame ionisation detection) and IRMS (isotope ratio mass spectrometry). In addition, flask sampling during aircraft flights was performed three times per day during early morning, midday and afternoon. The samples were taken at heights of 100 , 200, 300, 500, 700, 1000, 1500, 2000, 2500 and 3000 $\mathrm{m}$ above ground, and were analysed for $\mathrm{CO}_{2}$ mixing ratio and $\mathrm{CO}_{2}$ stable isotope ratios at LSCE (Laboratoire des Sciences du Climat et de l'Environnement), Saclay (Ramonet et al., 2002). ${ }^{222} \mathrm{Rn}$ was measured via its daughter activity with the static filter method at the same heights where flasks were taken with a time resolution of $60 \mathrm{~min}$ (Levin et al., 2002). In addition the ${ }^{222} \mathrm{Rn}$ soil exhalation rate was measured in the footprint of the tower with the inverted chamber method (Levin et al., 2002). On the same soil exhalation samples $\mathrm{CO}_{2}$ was also measured to determine the soil respiration flux of $\mathrm{CO}_{2}$ as well.

To characterise the ${ }^{13} \mathrm{C}$ and ${ }^{18} \mathrm{O}$ isotopic composition of $\mathrm{CO}_{2}$ exchanged with leaves and soil, in parallel to the flask sampling and continuous ${ }^{222} \mathrm{Rn}$ measurements, bulk leaf and soil material was sampled over the course of the intensive campaign. Sampling frequency was $4 \mathrm{~h}$ and was synchronised with the tower and aircraft sampling schedule. Deciduous tree leaves and coniferous tree needles have been sampled at two vertical levels (about $10 \mathrm{~m}$ and $22 \mathrm{~m}$ above ground) as well as moss and blueberry leaves and stems in duplicate with the same time resolution. Furthermore, once per day (around midday) a trunk wood core of each, the deciduous and the conifer tree was sampled, and a soil core $(60 \mathrm{~cm}$ depth) underneath each tree. Net ecosystem $\mathrm{CO}_{2}$ exchange was measured with the eddy covariance technique on top of the forest canopy at $28 \mathrm{~m}$ height. In addition, vertical $\mathrm{CO}_{2}$ concentration measurements at the tower were performed at 0.2 , 1.0, 2.0, 4.8, 10.8, 15.6, 25.2 and $28.0 \mathrm{~m}$, respectively, to determine the $\mathrm{CO}_{2}$ concentration profile within the forest canopy at high vertical resolution (Milyukova et al., 2002).

As the ${ }^{18} \mathrm{O}$ signature of water vapour is an important component of the total ${ }^{18} \mathrm{O}$ balance at the tower site, the water vapour samples from cryogenic drying of the ambient air were used for $\delta^{18} \mathrm{O}-\mathrm{H}_{2} \mathrm{O}$ analysis (time resolution of integrated samples: $4 \mathrm{~h}$ ). The design of the cold trap (see above) was optimised for minimum loss of water vapour at a dewpoint of $-40{ }^{\circ} \mathrm{C}$; the maximum change of the $\delta^{18} \mathrm{O}$ signature was determined not to exceed $+0.4 \%$ o. For ambient dew points between 10 and $25^{\circ} \mathrm{C}$, the cooling traps yield a $\mathrm{H}_{2} \mathrm{O}$ sampling efficiency of more than $99.8 \%$.

\subsection{Sample analysis}

$\mathrm{CO}_{2}$ mixing ratio on the flasks was measured in Heidelberg with an automated HP 5890 series II gas chromatograph equipped with a methaniser and flame ionisation detector (FID) (Greschner, 1995). The reproducibility of the $\mathrm{CO}_{2}$ concentration analyses $(1 \sigma)$ is better than $\pm 0.15 \mathrm{ppm}$. The stable isotope ratios of the canopy air samples were analysed in the Heidelberg laboratory with a Finnigan MAT 252 mass spectrometer, combined with a multiport trapping box for $\mathrm{CO}_{2}$ extraction (Neubert, 1998). Typical reproducibility for flask $\mathrm{CO}_{2}$ stable isotopes is $\pm 0.015 \%$ o $(1 \sigma)$ for $\delta^{13} \mathrm{C}$ and $\pm 0.03 \%$ o for $\delta^{18} \mathrm{O}-\mathrm{CO}_{2}$. Water vapour samples were stored in the original cold trap and were transferred in the laboratory to the equilibration unit of the mass spectrometer for ${ }^{18} \mathrm{O}$ analysis. The typical reproducibility of the $\delta^{18} \mathrm{O}-\mathrm{H}_{2} \mathrm{O}$ water vapour measurement (Finnigan MAT 252) is $\pm 0.02 \%$ o. Vegetation samples were stored in gas-tight glass bottles. Bulk water was extracted in the vacuum and analysed at the Laboratoire de Biogéochimie Isotopique, Université Pierre et Marie Curie in Paris (Bariac et al., 1990).

\section{Experimental results}

\subsection{Meteorological parameters}

During the 5 day measurement period the overall meteorological conditions are characterised by periodic, solar radiation induced diurnal cycles. As shown in Fig. 1, air temperature varied between $12^{\circ} \mathrm{C}$ during night and maximum values of $24^{\circ} \mathrm{C}$ during day, accompanied by anti-correlated variation of the relative humidity ranging between $85 \%$ during night and values of about $30-40 \%$ during the day. Also the horizontal wind above the canopy at $28 \mathrm{~m}$ shows significant diurnal cycles with night-time wind speeds between 1 and $2 \mathrm{~m} \mathrm{~s}^{-1}$ increasing up to $4 \mathrm{~m} \mathrm{~s}^{-1}$ during the day. Inspection of photosynthetically active radiation (PAR) clearly exhibits the solar radiation controlled behaviour of the canopy micrometeorology. PAR is zero between 9:40 pm and 4:20 am (local winter time) and reaches maximum values of about $1500 \mu \mathrm{mol}$ $\mathrm{m}^{-2} \mathrm{~s}^{-1}$ around $1 \mathrm{pm}$. The observed ${ }^{222} \mathrm{Rn}$ activity at 26.3 and $1.8 \mathrm{~m}$ height presented in Fig. 1 (lowest panel) also underlies this diurnal, periodic meteorological pattern. The mean ${ }^{222} \mathrm{Rn}$ soil exhalation rate for the catchment area of the tower site was determined to be $24 \pm 9.7 \mathrm{~Bq} \mathrm{~m}^{-2} \mathrm{~h}^{-1}$. ${ }^{222} \mathrm{Rn}$ soil exhalation fluxes 


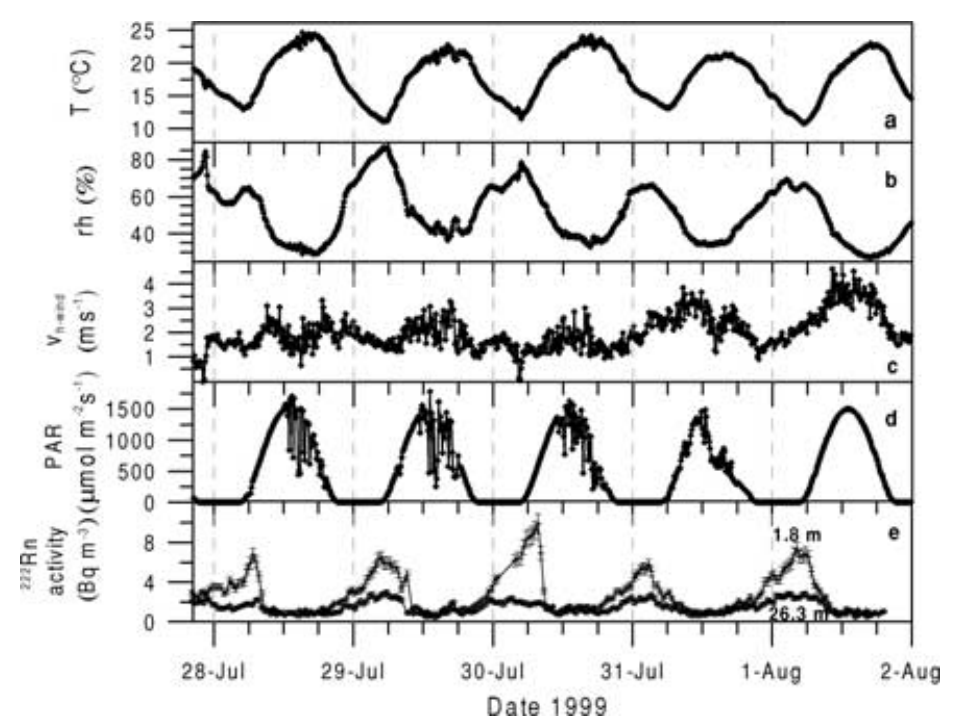

Fig. 1. Meteorological parameters observed during the intensive summer 1999 campaign at a height of $26.3 \mathrm{~m}$ : (a) temperature (T), (b) relative humidity $(\mathrm{rh}),(\mathrm{c})$ horizontal wind speed $\left(v_{\mathrm{h}-\text { wind }}\right)$, (d) photosynthetically active radiation (PAR), as well as (e) ${ }^{222} \mathrm{Rn}$ activity at two heights ( 26.3 and $1.8 \mathrm{~m}$, error bars indicate $10 \%$ statistical counting error).

showed a large variability along a hydrological measurement transect, which is due to the dramatically changing groundwater table depth (Levin et al., 2002). Atmospheric ${ }^{222} \mathrm{Rn}$ activities at both heights vary with a strong diurnal cycle, caused by an inversion buildup during night. The vertical gradient between top and bottom of the forest canopy then reaches values up to $8 \mathrm{~Bq} \mathrm{~m}^{-3}$. After sunrise, radiative heating initiates convective turbulence which rapidly destroys the accumulated vertical gradient. During day-time, ${ }^{222} \mathrm{Rn}$ activities at both heights reach similar values, suggesting the canopy air to be almost completely well mixed with the CBL.

\section{2. $\mathrm{CO}_{2}$ mixing ratio and stable isotope ratios}

Diurnal variations of $\mathrm{CO}_{2}$ mixing ratio and stable isotope ratios at two heights (1.8 and $26.3 \mathrm{~m}$ above ground) within the forest canopy measured on the flask samples are shown in Fig. 2. Depending on the meteorological conditions within the canopy, $\mathrm{CO}_{2}$ mixing ratio shows a strong diurnal cycle with maximum concentrations in the morning and minimum values during the afternoon. During the intensive campaign period, the diurnal $\mathrm{CO}_{2}$ amplitude at $1.8 \mathrm{~m}$ of $70-120 \mathrm{ppm}$ is much larger than that at $26.3 \mathrm{~m}$, which is only about $20 \mathrm{ppm}$. The $\mathrm{CO}_{2}$ respiration signal at $26.3 \mathrm{~m}$ is considerably smoothed by the mixing of canopy with CBL air during day-time, whereas the $1.8 \mathrm{~m}$ night time measurements strongly reflect the soil respiration flux signal when vertical mixing is suppressed during the build up of night-time inversions.

The diurnal cycles of stable isotopes are anticorrelated to the $\mathrm{CO}_{2}$ concentration cycle, which is expected for both $\delta^{13} \mathrm{C}$ and $\delta^{18} \mathrm{O}-\mathrm{CO}_{2}$. Assuming that the atmospheric $\mathrm{CO}_{2}$ concentration within the forest canopy air, $c_{\mathrm{e}}$, is a two-component mixture of some constant background air concentration, $c_{\mathrm{a}}$, and $\mathrm{CO}_{2}$ that is added or removed by sources and sinks, $c_{\mathrm{s}}$, within the ecosystem, the apparent isotopic signature of the source can be estimated according to:

$$
\delta_{\mathrm{e}}=\frac{c_{\mathrm{a}}\left(\delta_{\mathrm{a}}-\delta_{\mathrm{s}}\right)}{c_{\mathrm{e}}}+\delta_{\mathrm{s}}
$$

where $\delta_{\mathrm{a}}$ and $\delta_{\mathrm{s}}$ represent the isotopic composition of the atmospheric background air and of the source $\mathrm{CO}_{2}$, respectively (Keeling, 1961). This is a linear relationship between $\delta_{\mathrm{e}}$ and $1 / c_{\mathrm{e}}$ with a slope of $c_{\mathrm{a}}\left(\delta_{\mathrm{a}}-\delta_{\mathrm{s}}\right)$ and an intercept at $\delta_{\mathrm{s}}$ for $c_{\mathrm{e}} \rightarrow \infty$. Here it is important to note that this so-called Keeling plot can only be applied on a time scale at which the characteristic isotopic composition of the sources does not change. On the other hand, the Keeling plot delivers an overall isotopic source signature information, even if the ecosystem source/sink consists of several different components, as long as the relative contribution of 


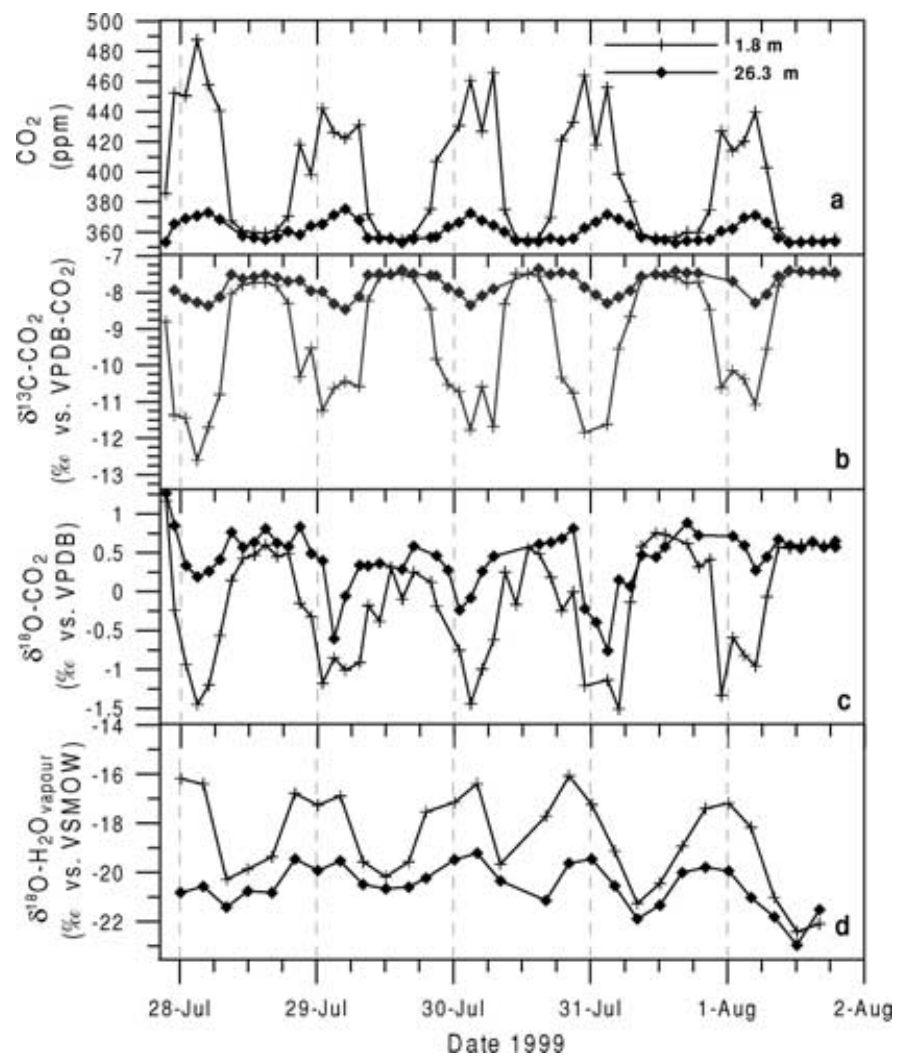

Fig. 2. Diurnal cycles of flask $\mathrm{CO}_{2}$ mixing ratio (a), $\delta^{13} \mathrm{C}-\mathrm{CO}_{2}$ (b), $\delta^{18} \mathrm{O}-\mathrm{CO}_{2}(\mathrm{c})$ and $\delta^{18} \mathrm{O}-\mathrm{H}_{2} \mathrm{O}$ of atmospheric water vapour (d) during the summer campaign in 1999 at two sampling heights, 26.3 and $1.8 \mathrm{~m}$ above ground.

each component does not change with time. The Keeling approach was used first to identify the contributions to the seasonal cycle (Keeling, 1961; Mook et al., 1983). More recently the identification of the isotopic composition of sources/sinks was also applied to terrestrial ecosystems (Buchmann et al., 1998; Yakir and Sternberg, 2000). The mean $\delta^{13} \mathrm{C}$ source signatures derived from the correlation with the inverse $\mathrm{CO}_{2}$ concentration for both heights [during day-time (concentration decrease) and night-time (concentration increase)] are given in Table 1.

The two-component mixing approach yields a consistent picture for the diurnal change of the $\delta^{13} \mathrm{C}$ apparent source signature within the canopy. For both heights the same source signatures of about $-24.8 \%$ ovs. VPDB- $\mathrm{CO}_{2}$ within a $1 \sigma$ uncertainty range were observed during day-time. During night-time the source is more depleted by about $1.8 \%$ o to $-26.6 \%$ o (Table 1). This $\delta^{13} \mathrm{C}$ day-time source signature illus-
Table 1. $\delta^{13} C$ Source signatures and their standard deviations derived from canopy observations ${ }^{\mathrm{a}}$

\begin{tabular}{llr}
\hline & \multicolumn{2}{c}{$\delta_{\mathrm{s}}^{13} \mathrm{C}\left(\%\right.$ vs. VPDB- $\left.\mathrm{CO}_{2}\right)$} \\
\cline { 2 - 3 } Period $^{\mathrm{b}}$ & $1.8 \mathrm{~m}$ height & $26.3 \mathrm{~m}$ height \\
\hline Overall & $-25.94 \pm 0.1$ & $-25.68 \pm 0.4$ \\
Day-time mean & $-24.79 \pm 0.5$ & $-24.73 \pm 0.4$ \\
Night-time mean & $-26.39 \pm 0.4$ & $-26.82 \pm 1.5$
\end{tabular}

${ }^{a}$ Accepted correlation coefficient $r^{2}$ used for the mean values: $r^{2}>0.95$

${ }^{b}$ Day-time: 7:00-19:00 local winter time. Night-time: 21:00-5:00 local winter time.

trates the strong assimilation discrimination influence on the ecosystem ambient $\mathrm{CO}_{2}$. Assimilation enrichment can also be observed for $\delta^{18} \mathrm{O}-\mathrm{CO}_{2}$, whereby the anticorrelation to the $\mathrm{CO}_{2}$ concentration variability is not as close as it is for $\delta^{13} \mathrm{C}$. Due to the isotopic 
equilibration exchange of oxygen isotopes with different water pools within the ecosystem, there is not necessarily a two-component mixing, and therefore no linear correlation between $\mathrm{CO}_{2}$ and $\delta^{18} \mathrm{O}-\mathrm{CO}_{2}$ is expected.

\section{3. ${ }^{18} \mathrm{O} /{ }^{16} \mathrm{O}$ in the water pools}

The variation of the $4 \mathrm{~h}$ integral water vapour $\delta^{18} \mathrm{O}-\mathrm{H}_{2} \mathrm{O}$ within the canopy is presented in Fig. $2 \mathrm{~d}$. A huge diurnal cycle and a vertical gradient are observed. Compared to the $1.8 \mathrm{~m} \mathrm{level,} \mathrm{at} 26.3 \mathrm{~m} \delta^{18} \mathrm{O}$ of water vapour is always more depleted with a diurnal cycle between -19.5 and $-22 \%$ (vs. VSMOW). The $1.8 \mathrm{~m}$ level shows a larger diurnal cycle than the $26.3 \mathrm{~m}$ level with most depleted values of about $-20 \%$ o during day and enriched values up to $-16 \%$ o during night. This diurnal cycle, as well as the vertical profile, can be interpreted as the mixture of evaporating soil and leaf water and tropospheric water vapour being significantly depleted compared to the evaporating water. As the evaporating soil water $\left(\delta^{18} \mathrm{O}-\mathrm{H}_{2} \mathrm{O}\right.$ about $-11 \%$ vs. VSMOW, Fig. 3a) should result in a water vapour $\delta^{18} \mathrm{O}-\mathrm{H}_{2} \mathrm{O}$ of about $-21 \%$ o, due to evaporation fractionation, a large portion of the evaporating water must originate from enriched reservoirs, i.e. from the leaves or condensed surface water on the plant leaves.
Two major schemes of the spatial and temporal evolution of the $\delta^{18} \mathrm{O}-\mathrm{H}_{2} \mathrm{O}$ composition of the vegetation and soil water pools are shown in Fig. 3a. Throughout the day, there is a general enrichment of the ${ }^{18} \mathrm{O} /{ }^{16} \mathrm{O}$ ratio from the bottom to the top of the ecosystem water pools. The soil water in the top layer of the soil $\left(0-5 \mathrm{~cm}\right.$ depth) has a $\delta^{18} \mathrm{O}-\mathrm{H}_{2} \mathrm{O}$ value of $-11.25 \%$ o (vs. VSMOW) (mean between soil under coniferous and deciduous dominated areas), whereby the soil water becomes depleted to about $-12.2 \%$ at a depth of $40 \mathrm{~cm}$, to stay nearly constant down to $60 \mathrm{~cm}$ depths (not shown in Fig. 3a). The mean (conifer and deciduous tree) stem water ${ }^{18} \mathrm{O} /{ }^{16} \mathrm{O}$ ratio of $-9.8 \%$ is enriched compared to the soil water by about $2 \%$. Stem water is assumed to represent the $\delta^{18} \mathrm{O}-\mathrm{H}_{2} \mathrm{O}$ of sap water that is delivered to leaves where it evaporates. For night-time with no assimilation activity, the enrichment can further be observed via the understory vegetation (mosses stem and leaves and blueberry stem) with an ${ }^{18} \mathrm{O} /{ }^{16} \mathrm{O}$ ratio from about $-5 \%$ o to $-2 \%$, followed by the blueberry leaves and the deciduous low level leaves with an ${ }^{18} \mathrm{O} /{ }^{16} \mathrm{O}$ ratio around $0 \%$ o. Highest values for $\delta^{18} \mathrm{O}-\mathrm{H}_{2} \mathrm{O}$ during night-time between $0 \%$ o and $+4 \%$ can be observed for the high and low levels of the coniferous needles as well as for the deciduous high level leaves. This reflects the fact that leaf water in trees does not relax back to the stem water isotope

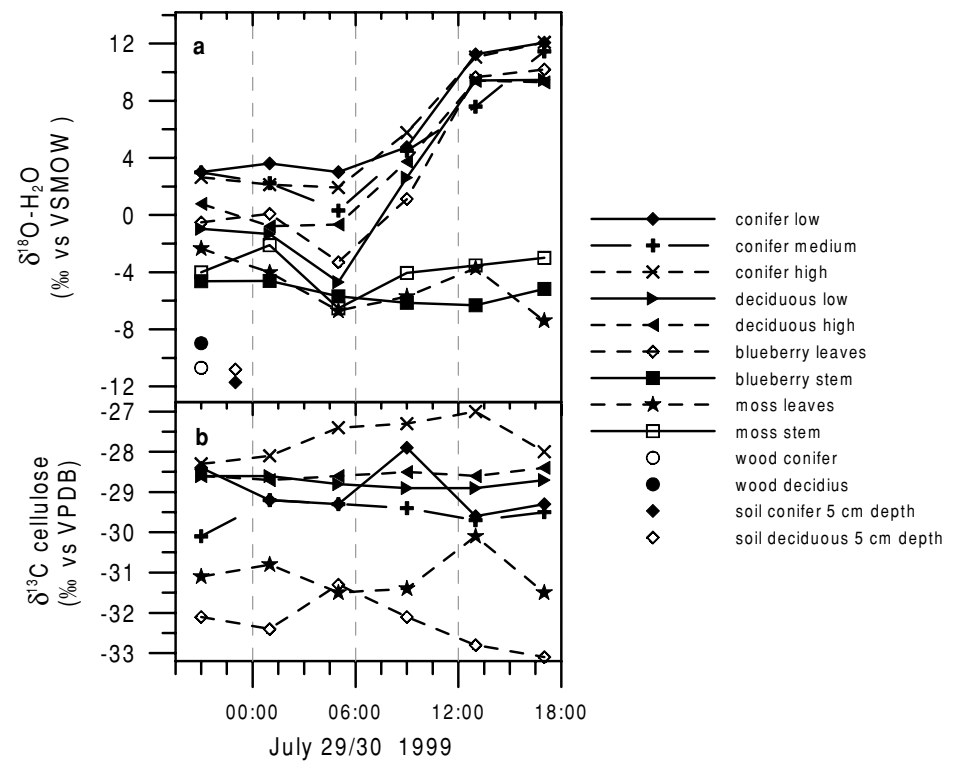

Fig. 3. Diurnal $\delta^{18} \mathrm{O}-\mathrm{H}_{2} \mathrm{O}$ variations of the different vegetation water pools along with soil and trunk $\delta^{18} \mathrm{O}-\mathrm{H}_{2} \mathrm{O}$ (a) and diurnal $\delta^{13} \mathrm{C}$ variations of plant tissue material (b).

Tellus 54B (2002), 5 
composition during the night in the absence of assimilation. The second dominant pattern of the ${ }^{18} \mathrm{O}$ signature in the water pools is the difference in their diurnal cycles. Basically, the vertical gradient is maintained, but except for the blueberry and moss stems and the moss leaves, a strong enrichment of about $10 \%$ o during day-time is detected for all other leaf compartments within the tree leaves.

The ${ }^{13} \mathrm{C} /{ }^{12} \mathrm{C}$ ratios of the plant cellulose are presented in Fig. 3b. As expected, no pronounced diurnal cycle can be observed for ${ }^{13} \mathrm{C}$ of the plant tissue. However, there is a clear vertical gradient towards more enriched values beginning from the understory blueberries and mosses $\left(\delta^{13} \mathrm{C}=-31\right.$ to $-33 \%$ ) to the respective levels of the tree leaves $\left(\delta^{13} \mathrm{C}=-27\right.$ to $-30 \%$ ). This principal vertical gradient can be due to a higher assimilative re-fixation rate of soil respired and therefore more depleted $\mathrm{CO}_{2}$ for understory vegetation compared to the upper canopy tree leaves, which assimilate more enriched $\mathrm{CO}_{2}$ originating from the $\mathrm{CBL}$.

\section{4. $\delta^{18} \mathrm{O}$ Model set-up}

The main objective of the modelling approach is to investigate the potential of the ${ }^{18} \mathrm{O}$ isotopic composition of carbon dioxide and associated water pools to determine the gross $\mathrm{CO}_{2}$ fluxes of the ecosystem. As the $\delta^{18} \mathrm{O}-\mathrm{CO}_{2}$ variability within the forest canopy is controlled by both, transport-driven exchange of canopy $\mathrm{CO}_{2}$ with the CBL and processrelated biospheric activity impact, the model has to be well parameterised with respect to transport before the biological processes can be investigated. A onedimensional box-model set-up was chosen to differentiate between the respective carbon dioxide and water pools, whereby three boxes with quasi-logarithmic height scaling from bottom to top are investigated for their turbulent transport and assimilative and respirative exchange fluxes (Fig. 4). The lowest box (box 1, from soil surface to $4 \mathrm{~m}$ height) represents the interface with the soil and the understory vegetation regime, the second box (box 2 , from $4 \mathrm{~m}$ to $26 \mathrm{~m}$ height) represents the deciduous and coniferous tree activity within the canopy, whereas box 3 (box 3, from $26 \mathrm{~m}$ to $400 \mathrm{~m}$ ) represents the CBL. Box 2 communicates with box 3 and box 1 via turbulent exchange.

\section{1. $\mathrm{CO}_{2}$ mass balance}

Setting up a mass balance to describe formally the respective $\mathrm{CO}_{2}$ fluxes, it is useful to consider a column

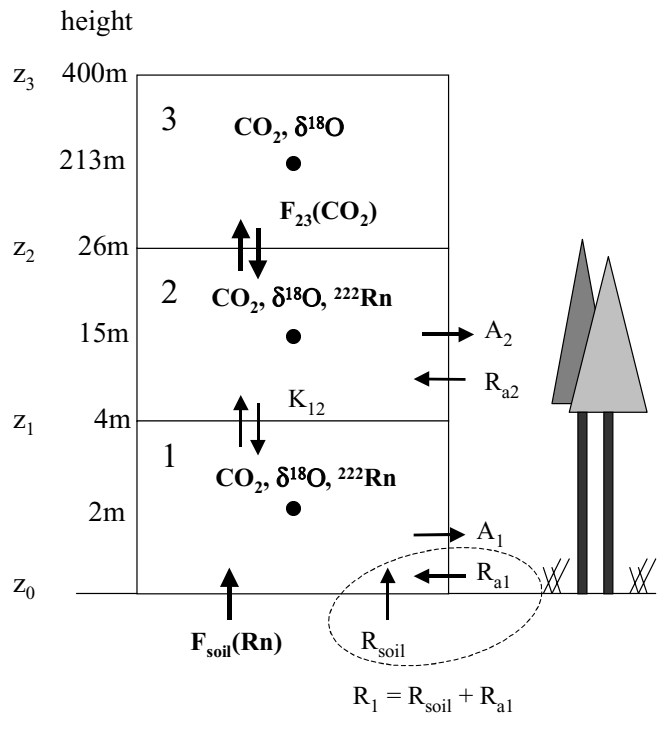

Fig. 4. Scheme of the canopy box model set-up: the measured input values are in bold characters, the calculated model output values are in normal characters.

of air extending from the soil surface to a height, $H$, within or above the canopy. The mass balance of $\mathrm{CO}_{2}$ in such an air column within an ecosystem canopy, in case of no horizontal advection of $\mathrm{CO}_{2}$, is given by eq. (2) [the convention for the algebraic signs are: inward fluxes (into the canopy column) are calculated positive, outward fluxes negative]:

$\frac{H}{V_{\mathrm{mol}}} \cdot \frac{\mathrm{d}\left[\mathrm{CO}_{2}\right]}{\mathrm{d} t}=-A+R+F_{\mathrm{ae}}\left(\mathrm{CO}_{2}\right)$

where $V_{\mathrm{mol}}$ is the molar volume of air $\left[\mathrm{m}^{3} \mathrm{~mol}(\text { air })^{-1}\right]$, $H$ is the height of the air column (m), $\left[\mathrm{CO}_{2}\right]$ is the average mole fraction of $\mathrm{CO}_{2}$ within the column $\left[\mathrm{mol}\left(\mathrm{CO}_{2}\right)\right.$ $\operatorname{mol}(\text { air })^{-1}$ ], $R$ is the $\mathrm{CO}_{2}$ respiration flux, given by $R_{\text {soil }}+R_{\text {a }}\left[\mathrm{mol}\left(\mathrm{CO}_{2}\right) \mathrm{m}^{-2} \mathrm{~h}^{-1}\right], R_{\text {soil }}$ is the $\mathrm{CO}_{2}$ respiration flux from soil (heterotrophic and autotrophic) [mol $\left.\left(\mathrm{CO}_{2}\right) \mathrm{m}^{-2} \mathrm{~h}^{-1}\right], R_{\mathrm{a}}$ is the above-ground $\mathrm{CO}_{2}$ respiration flux [mol $\left.\left(\mathrm{CO}_{2}\right) \mathrm{m}^{-2} \mathrm{~h}^{-1}\right], A$ is the net $\mathrm{CO}_{2}$ assimilation flux by the foliage within the column [mol $\left(\mathrm{CO}_{2}\right) \mathrm{m}^{-2} \mathrm{~h}^{-1}$, and $F_{\text {ae }}$ is the flux of $\mathrm{CO}_{2}$ between the air column and the atmosphere above $\left(\mathrm{mol}\left[\mathrm{CO}_{2}\right)\right.$ $\left.\mathrm{m}^{-2} \mathrm{~h}^{-1}\right]$.

Within a canopy, it is a priori not the case, and in fact never observed in reality, that there is no gradient of $\mathrm{CO}_{2}$ concentration within a column of air from a height $z$ to a height $z+\Delta z$. Depending on the canopy structure and meteorological conditions, there 
is usually a typical strong night-time gradient of up to $100 \mu \mathrm{mol}\left(\mathrm{CO}_{2}\right) / \mathrm{mol}$ (air) between bottom and top due to suppressed vertical mixing. Therefore, the average mixing ratio

$$
\overline{\left[\mathrm{CO}_{2}(\Delta z)\right]}=\frac{1}{z_{\max }-z_{\min }} \int_{z_{\min }}^{z_{\max }}\left[\mathrm{CO}_{2}(z)\right] \mathrm{d} z
$$

must be calculated, to avoid a possible $\mathrm{CO}_{2}$ storage term being missing in eq. (2). To parameterise the intracanopy turbulent transport between box 1 and box 2 we used the soil-borne atmospheric ${ }^{222} \mathrm{Rn}$ activity as a tracer. The ${ }^{222} \mathrm{Rn}$ flux from the lowermost canopy box, box 1 , to the adjacent canopy box 2 can be calculated using the mean measured soil ${ }^{222} \mathrm{Rn}$ exhalation rate $F_{\text {soil }}(\mathrm{Rn})$, and the atmospheric ${ }^{222} \mathrm{Rn}$ activity change with time in box 1 :

$H_{1} \frac{\mathrm{dRn}_{1}}{\mathrm{~d} t}=F_{\text {soil }}(\mathrm{Rn})-F_{12}(\mathrm{Rn})$.

In analogy to Fick's first law, the turbulent diffusion coefficient, $K_{12}$, can be formulated via the measured vertical ${ }^{222} \mathrm{Rn}$ gradient between box 1 and box 2 and the distance between the box centres $\Delta z$ according to:

$K_{12}=\frac{F_{12}(\mathrm{Rn}) \Delta z}{\left(\mathrm{Rn}_{1}-\mathrm{Rn}_{2}\right)}$

Mean ${ }^{222} \mathrm{Rn}$ activities and $\mathrm{CO}_{2}$ mixing ratios for each canopy box are calculated by integration of the measured $\mathrm{CO}_{2}$ profiles (Milyukova et al., 2002), assuming a similarity between ${ }^{222} \mathrm{Rn}$ and $\mathrm{CO}_{2}$, with:

$$
\overline{\left[\mathrm{CO}_{2 \text { profile }}\right]}=\frac{1}{z_{\max }-z_{\min }} \int_{z_{\min }}^{z_{\max }}\left[\mathrm{CO}_{2 \text { profile }}(z)\right] \mathrm{d} z \text {. }
$$

The $\mathrm{CO}_{2}$ flask mixing ratios and ${ }^{222} \mathrm{Rn}$ activities, which are both measured at heights $z=1.8$ and $z=$ $26.3 \mathrm{~m}$, respectively, are subsequently scaled to their mean value of each box by assuming:

$\overline{\left[\mathrm{CO}_{2 \text { flasks }}\right]}=\frac{\left[\overline{\left.\mathrm{CO}_{2 \text { profile }}\right]}\right.}{\left[\mathrm{CO}_{2 \text { profile }}(z)\right]}\left[\mathrm{CO}_{2 \text { flasks }}(z)\right]$

and

$\overline{\mathrm{Rn}}=\frac{\overline{\left[\mathrm{CO}_{2 \text { profile }}\right]}}{\left[\mathrm{CO}_{2 \text { profile }}(z)\right]} \mathrm{Rn}(z)$.

The isotopes measured at both heights are assumed to represent the mean box values. The $\mathrm{CO}_{2}$ flux between box 1 and box 2 is then calculated using the ${ }^{222} \mathrm{Rn}$ derived $K_{12}$ via [see eqs. (4) and (5)]:

$F_{12}\left(\mathrm{CO}_{2}\right)=K_{12} \frac{\left[\mathrm{CO}_{2}\right]_{1}-\left[\mathrm{CO}_{2}\right]_{2}}{\Delta z V_{\mathrm{mol}}}$.
As shown in Fig. 1e, within the measurement uncertainty of about $10 \%$ there is always a negative gradient in ${ }^{222} \mathrm{Rn}$ activity between bottom and top of the canopy. Therefore, the exchange coefficient $K_{12}$ will always be positive as long as there is a positive flux $F_{12}(\mathrm{Rn})$ from box 1 to box 2 in eq. (4). The $\mathrm{CO}_{2}$ flux from box 2 to box 3 is taken from the measured eddy covariance flux (Milyukova et al., 2002). The $\mathrm{CO}_{2}$ mass balance equations for box 1 and box 2, respectively, can then be written as:

$$
\begin{aligned}
\frac{H_{1}}{V_{\mathrm{mol}}} \frac{\mathrm{d}\left[\mathrm{CO}_{2}\right]_{1}}{\mathrm{~d} t}= & -A_{1}+R_{\text {soil }}+R_{\mathrm{a} 1}-F_{12}\left(\mathrm{CO}_{2}\right) \\
\frac{\mathrm{H}_{2}}{V_{\mathrm{mol}}} \frac{\mathrm{d}\left[\mathrm{CO}_{2}\right]_{2}}{\mathrm{~d} t}= & -A_{2}+R_{a 2} \\
& +F_{12}\left(\mathrm{CO}_{2}\right)-F_{23}\left(\mathrm{CO}_{2}\right) .
\end{aligned}
$$

Equations (10) and (11) contain five unknowns, namely the assimilation terms in each box, $A_{1}$ and $A_{2}$, the autotrophic plant respiration terms in each box, $R_{\mathrm{a} 1}$ and $R_{\mathrm{a} 2}$, and the overall soil respiration (autotrophic plus heterotrophic respiration) term in box $1, R_{\text {soil }}$. To determine the unknowns, we have to introduce more equations, and therefore include the ${ }^{18} \mathrm{O} /{ }^{16} \mathrm{O}$ ratio information of the canopy air $\mathrm{CO}_{2}$ and of $\mathrm{CO}_{2}$ isotopically equilibrated with vegetation water pools, along with the respective isotope discriminations.

\section{2. $\delta^{18} \mathrm{O}$ mass balance}

The mass balance for both canopy boxes 1 and 2 can be formulated as:

$$
\begin{aligned}
& \frac{H_{1}\left[\mathrm{CO}_{2}\right]_{1}}{V_{\text {mol }}} \frac{\mathrm{d} \delta^{18} \mathrm{O}_{1}}{\mathrm{~d} t}=A_{1} \Delta_{\text {leaves } 1} \\
& +R_{\text {soil }}\left(\delta^{18} \mathrm{O}_{\text {soil }}-\delta^{18} \mathrm{O}_{1}\right. \\
& \left.+\varepsilon_{\text {soil }}\right)+R_{\mathrm{a} 1}\left(\delta^{18} \mathrm{O}_{\text {stem } 1}\right. \\
& \left.-\delta^{18} \mathrm{O}_{1}+\varepsilon_{\text {stem }}\right)-F_{1 \rightarrow 2}\left(\mathrm{CO}_{2}\right) \\
& \times\left(\delta^{18} \mathrm{O}_{1}-\delta^{18} \mathrm{O}_{2}\right) \\
& \frac{\mathrm{H}_{2}\left[\mathrm{CO}_{2}\right]_{2}}{V_{\text {mol }}} \frac{\mathrm{d} \delta^{18} \mathrm{O}_{2}}{\mathrm{~d} t}=A_{2} \Delta_{\text {leaves } 2} \\
& +R_{\mathrm{a} 2}\left(\delta^{18} \mathrm{O}_{\text {stem } 2}-\delta^{18} \mathrm{O}_{2}\right. \\
& \left.+\varepsilon_{\text {stem }}\right)+F_{1 \rightarrow 2}\left(\mathrm{CO}_{2}\right) \\
& \times\left(\delta^{18} \mathrm{O}_{1}-\delta^{18} \mathrm{O}_{2}\right) \\
& -F_{2 \rightarrow 3}\left(\mathrm{CO}_{2}\right)\left(\delta^{18} \mathrm{O}_{2}-\delta^{18} \mathrm{O}_{3}\right)
\end{aligned}
$$

Tellus 54B (2002), 5 
where $\Delta_{\text {leaves }}$ is the leaf discrimination against $\mathrm{C}^{16} \mathrm{O}^{18} \mathrm{O}$ in the respective box, and $\delta^{18} \mathrm{O}_{\text {soil }}$ and $\delta^{18}$ $\mathrm{O}_{\text {stem }}$ the isotopic composition of soil $\mathrm{CO}_{2}$ and stem $\mathrm{CO}_{2}$ in isotopic equilibrium with soil or stem water, respectively. $\delta^{18} \mathrm{O}_{\mathrm{i}}$ is the isotopic composition of atmospheric $\mathrm{CO}_{2}$ in box i, $\varepsilon_{\text {soil }}$ the effective soil fractionation during diffusion [-7.2\%o (Miller et al., 1999)] and $\varepsilon_{\text {stem }}$ the effective fractionation during diffusion from stem to atmosphere $(-8.8 \%)$. We will call the difference between $\delta^{18} \mathrm{O}-\mathrm{CO}_{2}$ leaving the soil minus $\delta^{18} \mathrm{O}$ of atmospheric $\mathrm{CO}_{2}$ soil "discrimination", $\Delta_{\mathrm{s}}=\delta^{18} \mathrm{O}_{\text {soil }}-\delta^{18} \mathrm{O}_{\mathrm{i}}+\varepsilon_{\text {soil }}$, in quotation marks because it is no real discrimination. We apply the same to stem respiration. Combining eqs. (10)-(13) yields a system with four equations and five unknowns. Therefore, to solve this system of differential equations, it is assumed that the ratio of $R_{\mathrm{a} 1} /\left(R_{\text {soil }}+R_{\mathrm{a} 1}\right)=\beta$ in box 1 is about 0.3 , i.e. autotrophic stem respiration is about $30 \%$ of the total respiration flux of the understory vegetation in box 1 (Milyukova et al., 2002). Therefore, in eq. (13) $R_{\mathrm{a} 1}$ and $R_{\text {soil }}$ are summarised to one overall respiration flux in box $1, R_{1}$, whereby the respective isotopic $\Delta_{\mathrm{s}}$ are weighted by the factors $1-\beta$ and $\beta$, respectively. In case of complete isotopic equilibrium between $\mathrm{CO}_{2}$ and water before the assimilation fixation of $\mathrm{CO}_{2}$, the discrimination for ${ }^{18} \mathrm{O}$ is given by (Farquhar and Lloyd, 1993):

$\Delta_{\text {leaves }}=-\varepsilon_{\text {leaf }}+\frac{c_{\mathrm{c}}}{c_{\mathrm{e}}-c_{\mathrm{c}}}\left(\delta^{18} \mathrm{O}_{\text {leaf }}-\delta^{18} \mathrm{O}_{\mathrm{e}}\right)$

where $c_{\mathrm{c}}$ is the chloroplast $\mathrm{CO}_{2}$ concentration, $\delta^{18} \mathrm{O}_{\text {leaf }}$ the isotopic composition of leaf $\mathrm{CO}_{2}$ in isotopic equilibrium with the measured leaf bulk water, $\delta^{18} \mathrm{O}_{\mathrm{e}}$ the atmospheric ecosystem ${ }^{18} \mathrm{O}$ of $\mathrm{CO}_{2}$ and $\varepsilon_{\text {leaf }}$ the mean effective fractionation during diffusion from the atmosphere to the site of carboxylation within the leaf (-7.4\%o, Farquhar et al., 1993).

In order to parameterise $c_{\mathrm{i}}$ and $c_{\mathrm{c}}$ we used the functional relation between the ${ }^{13} \mathrm{C}$ isotopic composition of the plant and the ${ }^{13} \mathrm{C}$ isotopic composition of ambient $\mathrm{CO}_{2}$, depending on the ratio of the $\mathrm{CO}_{2}$ concentration in the sub-stomata cavities, $c_{\mathrm{i}}$, to ambient ecosystem $\mathrm{CO}_{2}$ concentration, $c_{\mathrm{e}}$ (Farquhar et al., 1982). Considering the diffusion fractionation of ${ }^{13} \mathrm{CO}_{2}$ in air, $\varepsilon_{\mathrm{d}}=4.4 \%$, and the carboxylation fractionation for $\mathrm{C} 3$ plants, $\varepsilon_{\mathrm{c}}=27 \%$, the plant $\mathrm{CO}_{2}$ concentration in the sub-stomata cavities can be calculated as:

$c_{\mathrm{i}}=c_{\mathrm{e}}\left(\frac{\delta^{13} \mathrm{C}_{\mathrm{e}}-\delta^{13} \mathrm{C}_{\mathrm{cell}}-\varepsilon_{\mathrm{d}}}{\varepsilon_{\mathrm{c}}-\varepsilon_{\mathrm{d}}}\right)$.
Leaf-scale measurements of the $\mathrm{CO}_{2}$ concentration $c_{\mathrm{i}}$ suggest a further $\mathrm{CO}_{2}$ concentration draw-down to the chloroplast $c_{\mathrm{c}}$. This decline is estimated to range from $\left(c_{\mathrm{i}}-c_{\mathrm{c}}\right) / \mathrm{c}_{\mathrm{e}} \sim 0.1$ (Farquhar et al., 1993) via $\left(c_{\mathrm{i}}-c_{\mathrm{c}}\right) / \mathrm{c}_{\mathrm{e}} \sim 0.15$ (Raven and Glidewell, 1981) to $\left(c_{\mathrm{i}}-c_{\mathrm{c}}\right) / \mathrm{c}_{\mathrm{e}} \sim 0.2$ (Lloyd et al., 1992). Equation (15) calculates precisely $c_{\mathrm{c}}$, but measurements to determine $\varepsilon_{\mathrm{c}}$ are made mostly via $c_{\mathrm{i}}$. Farquhar et al. (1989) suggest a value of $\varepsilon_{\mathrm{c}}=29 \%$ if one takes $c_{\mathrm{c}}$ and a value of $\varepsilon_{\mathrm{c}}=27 \%$ o if one takes $c_{\mathrm{i}}$. Our approach is based completely on measurements, so that we prefer to take $c_{\mathrm{i}}$ and make a sensitivity analysis afterwards. In any case, $c_{\mathrm{c}}$ in eq. (14) is only a first approximation of the "real" concentration at which $\mathrm{CO}_{2}$ equilibrates with leaf water. Measurements of Gillon and Yakir (2000) suggest that the equilibration takes place at a $\mathrm{CO}_{2}$ concentration somewhere between $c_{\mathrm{i}}$ and $c_{\mathrm{c}}$. They suggest that it may be the surface of the chloroplasts. However, their values vary in the same range as mentioned for $c_{\mathrm{c}}$ before and are in the range of our sensitivity analysis (see below).

Besides the value of the leaf water isotopic composition, $\delta^{18} \mathrm{O}_{\text {leaf }}$, the mean diffusion fractionation factor of $\mathrm{C}^{16} \mathrm{O}^{18} \mathrm{O}$ from the leaf surface layer to the site of carboxylation, $\varepsilon_{\text {leaf }}$ in eq. (14), determines the value of the overall discrimination against $\mathrm{C}^{16} \mathrm{O}^{18} \mathrm{O}$. $\varepsilon_{\text {leaf }}$ represents an average value weighted over the different diffusive steps from the leaf surface to the stomata. Farquhar and Lloyd (1993) give an expression for the weighted mean discrimination factor along the concentration gradient from the atmosphere $\left(c_{\mathrm{e}}\right)$, via the leaf surface layer $\left(c_{\text {sur }}\right)$, the stomata, the intercellular spaces $\left(c_{\mathrm{i}}\right)$, mesophyll walls $\left(c_{\mathrm{mw}}\right)$ down to the site of carboxylation $\left(c_{\mathrm{c}}\right)$ as:

$\varepsilon_{\text {leaf }}=\frac{\left(c_{\mathrm{e}}-c_{\mathrm{sur}}\right) \varepsilon_{\mathrm{b}}+\left(c_{\mathrm{sur}}-c_{\mathrm{mw}}\right) \varepsilon_{\mathrm{d}}+\left(c_{\mathrm{mw}}-c_{\mathrm{c}}\right) \varepsilon_{\mathrm{w}}}{c_{\mathrm{e}}-c_{\mathrm{c}}}$

where $\varepsilon_{\mathrm{d}}$ is the fractionation factor for molecular diffusion through the stomata $(-8.8 \%), \varepsilon_{\mathrm{b}}$ is the fractionation factor for diffusion through the leaf boundary layer $(-5.8 \%$ ) , molecular diffusion to the $2 / 3$ power (Kays, 1966), and $\varepsilon_{\mathrm{w}}$ is the fractionation factor summarising an equilibrium dissolution effect and diffusion fractionation in solution at the mesophyll cell walls $(-0.8 \%$ ) (Farquhar and Lloyd, 1993).

During day time it can be assumed that the $\mathrm{CO}_{2}$ concentration at the turbulent air leaf boundary layer $c_{\text {sur }}$ is about a few percent lower than the ambient concentration $c_{\mathrm{e}}$. It was also observed that there is a decline in $\mathrm{CO}_{2}$ concentration from the sub-stomata 
cavities, $c_{\mathrm{i}}$, to the mesophyll cell walls, $c_{\mathrm{mw}}$, of less than 20 ppm (Farquhar and Rashke, 1978). The effective leaf discrimination for each model time step (30 min), considering the draw-down of the respective concentrations from the canopy air to the chloroplasts, can be calculated with the following assumptions: $c_{\mathrm{e}}$ is the measured atmospheric ecosystem $\mathrm{CO}_{2}$ concentration; $c_{\text {sur }}=c_{\mathrm{a}}-0.01 c_{\mathrm{a}}$ and is the $\mathrm{CO}_{2}$ mixing ratio at leaf surface; $c_{\mathrm{i}}$ follows from eq. (15) and is the $\mathrm{CO}_{2}$ mixing ratio in sub-stomata cavity; $c_{\mathrm{mw}}=c_{\mathrm{i}}-5 \mathrm{ppm}$ and is the $\mathrm{CO}_{2}$ mixing ratio at the mesophyll cell wall surface; $c_{\mathrm{c}}=c_{\mathrm{i}}-0.2 c_{\mathrm{a}}$ and is the $\mathrm{CO}_{2}$ mixing ratio in chloroplast.

However, for the standard simulation we use the average value of $\varepsilon_{\text {leaf }}=-7.4 \%$ o to calculate the overall $\Delta_{\text {leaves }}$, according to eq. (14) using $\delta^{18} \mathrm{O}_{\text {leaf }}$, the isotopic composition of leaf $\mathrm{CO}_{2}$ in $93 \%$ isotopic equi- librium (Gillon and Yakir, 2000) with the measured bulk leaf water at ambient air temperature following Brenninkmeijer et al. (1983) and $\left(c_{\mathrm{i}}-c_{\mathrm{c}}\right) / c_{\mathrm{e}} \sim 0.2$ (Lloyd et al., 1992).

\subsection{Model input data}

A constant ${ }^{222} \mathrm{Rn}$ soil exhalation rate of $10 \mathrm{~Bq}$ $\mathrm{m}^{-2} \mathrm{~s}^{-1}$ is used in the standard simulation. For box 3 the aircraft flasks were used to calculate the mean of this box for both, $\mathrm{CO}_{2}$ mixing ratio and $\delta^{18} \mathrm{O}-\mathrm{CO}_{2}$, with the heights at 100, 200 and $300 \mathrm{~m}$. All measured data records used as input for the model are linearly interpolated to the same time step ( $30 \mathrm{~min}$ ), and afterwards a harmonic fit is applied to the data. The harmonic curve-fitting is done with the technique developed by the NOAA/CMDL Carbon Cycle Group and is documented by Thoning et al. (1989). Figure 5 shows the

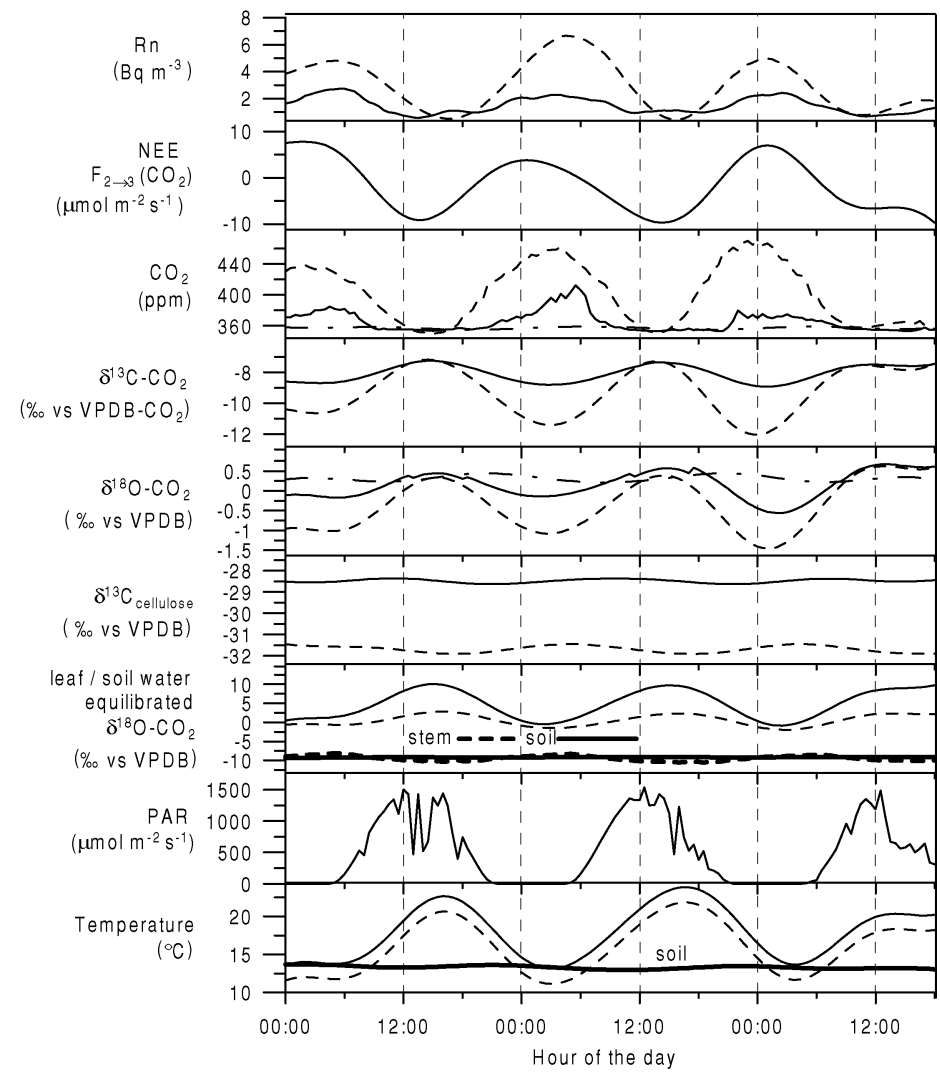

Fig. 5. Model input data: dashed lines represent box 1, solid lines box 2 and dash-dotted lines box 3. NEE represents the $\mathrm{CO}_{2}$ flux from box 2 to $3, F_{23}\left(\mathrm{CO}_{2}\right)$. Note the different scales of the smoothed curves compared to Figs. 1 and 2 . The model input curves represent the measured data of 29-31 July 1999; small discrepancies between data and curves are due to the smoothing procedure.

Tellus 54B (2002), 5 


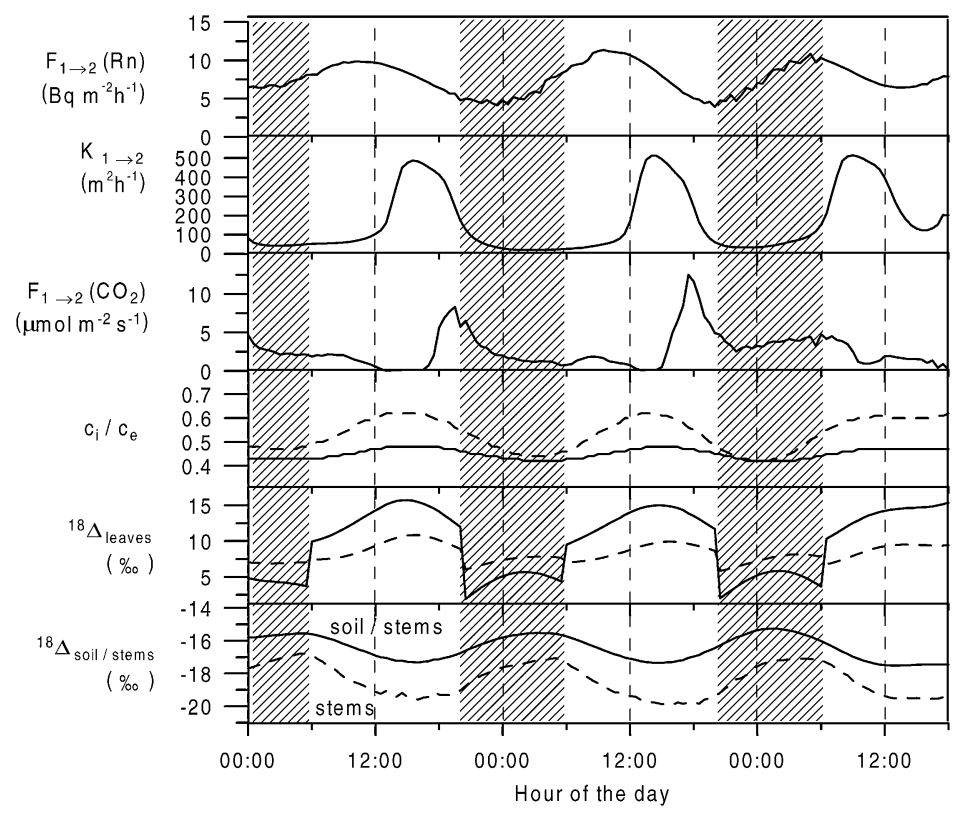

Fig. 6. Calculated model parameters: dashed lines represent box 1 and solid lines box 2. Note that during night (shaded area, by definition PAR $<150 \mu \mathrm{mol} \mathrm{m}^{-2} \mathrm{~s}^{-1}$ ) the assimilation flux is set to zero.

respective, smoothed model input records representing the measured data from 29 to 31 July 1999.

Figure 6 shows the calculated parameters of the model which determine the equation system (10)(13). The transport from box 1 to box 2 underlies a strong diurnal cycle as illustrated by the variability of $F_{12}(\mathrm{Rn})$ and $K_{12}$. During night, vertical exchange is suppressed with an exchange coefficient $K_{12}$ of about $50 \mathrm{~m}^{2} \mathrm{~h}^{-1}$, which rapidly increases around noon up to values of about $500 \mathrm{~m}^{2} \mathrm{~h}^{-1}$. However, the $\mathrm{CO}_{2}$ flux from box 1 to box 2 calculated by eq. (9) shows a different behaviour. Despite an increasing exchange coefficient $K_{12}$ around noon, the $\mathrm{CO}_{2}$ flux from box 1 to box 2 is nearly zero. This is due to the very small vertical $\mathrm{CO}_{2}$ gradient between the mean $\mathrm{CO}_{2}$ mixing ratios of both boxes. This gradient approaches zero and even becomes slightly positive (box 2 higher than box 1, Fig. 5). Therefore, in the model a minimum vertical gradient of $0.3 \mathrm{ppm}$ (twice the standard reproducibility of the flask measurement) is fixed, whenever the measured gradient falls below $0.3 \mathrm{ppm}$. With the build up of the vertical $\mathrm{CO}_{2}$ gradient in the afternoon/evening, accompanied by still high exchange coefficients $K_{12}$, the $\mathrm{CO}_{2}$ transport from box 1 to box 2 increases to maximum values of about $7-15 \mu \mathrm{mol} \mathrm{m}{ }^{-2} \mathrm{~s}^{-1}$. Here, the gradient box model approach obviously reaches a limit, because during strong vertical diffusion the flux is highly sensitive to very small gradients.

The ratio of sub-stomata cavity to ecosystem $\mathrm{CO}_{2}$ concentration, $c_{\mathrm{i}} / c_{\mathrm{e}}$, is calculated via eq. (15). Note here that only the day-time values are reasonable. In reality, during night-time, sub-stomata cavity $\mathrm{CO}_{2}$ concentrations can reach values of several thousand ppm, due to missing assimilation activity and the dominating leaf respiration. Therefore, the model ignores the night-time $c_{\mathrm{i}} / c_{\mathrm{e}}$ ratios, and the assimilation flux is forced to be zero. Consequently, the calculation of the overall leaf discrimination against $\mathrm{C}^{16} \mathrm{O}^{18} \mathrm{O}, \Delta_{\text {leaves }}$, which depends on $c_{\mathrm{i}} / c_{\mathrm{e}}$ [eq. (14)], is also only relevant for the flux equation system (10)-(13) during day-time. $c_{\mathrm{i}} / c_{\mathrm{e}}$ ratios are modelled to vary between 0.4 and 0.6 , values that are also observed elsewhere for C3 plants (Yakir and Sternberg, 2000). The overall leaf discrimination against $\mathrm{C}^{16} \mathrm{O}^{18} \mathrm{O}$ basically follows the diurnal cycle of the mean leaf water isotopic composition in the respective box (Fig. 5). The diurnal cycle amplitudes range from about 7 to $10 \%$ ofor box 1 and from about 10 to $16 \%$ o for box 2 . Here comparison of $\Delta_{\text {leaves }}$ with the discrimination against $\mathrm{C}^{16} \mathrm{O}^{18} \mathrm{O}$ by the soil $\Delta_{\text {soil }}$ and the stems $\Delta_{\text {stems }}$, respectively, exhibits the potential of $\delta^{18} \mathrm{O}-\mathrm{CO}_{2}$ as a unique tracer: the imprint of the soils and stem respiration, respectively, on 


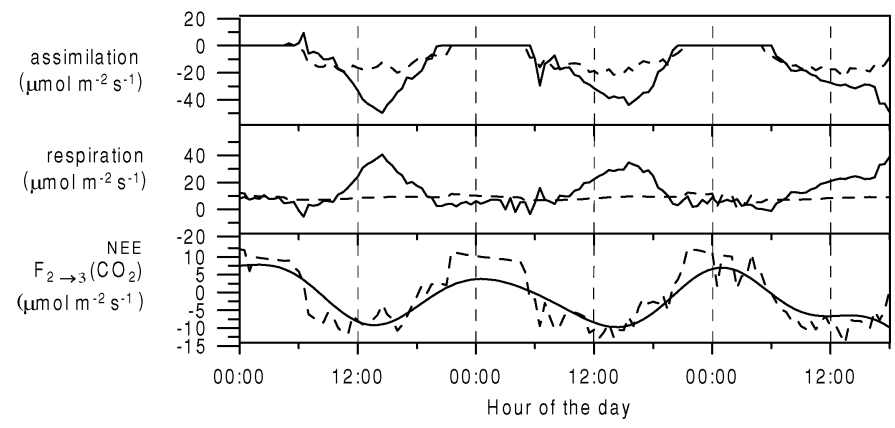

Fig. 7. Model output of the standard simulation (solid lines): the gross fluxes (sum of box 1 and box 2), assimilation and respiration, along with the net exchange flux $F_{23}\left(\mathrm{CO}_{2}\right)$ at the top of the canopy (original input function to the model, Fig. 5). The dashed lines show the results of separated assimilation and respiration fluxes derived from the modified Lloyd and Taylor (1994) model, based on NEE measurements (Milyukova et al., 2002).

the ecosystem $\delta^{18} \mathrm{O}-\mathrm{CO}_{2}$, is depleted by about $30 \%$, compared to the leaves. $\Delta_{\text {soil }}$ and $\Delta_{\text {stems }}$ show only a small temperature-driven variability, with a peakto-peak amplitude of about $1-2 \%$, and mean values around $-18 \%$ and $-16 \%$, respectively.

\section{Model results}

\subsection{Standard simulation}

The model output gross fluxes of the standard simulation are presented in Fig. 7 (solid lines). Assimilation fluxes are modelled to direct into the canopy, and they follow a diurnal cycle similar to PAR. During day-time the model calculates assimilation fluxes resulting in maximum values between 40 and $50 \mu \mathrm{mol}$ $\mathrm{m}^{-2} \mathrm{~s}^{-1}$ around noon. Simultaneously, to balance the mass flow, respiration is increasing up to about 30 $40 \mu \mathrm{mol} \mathrm{m} \mathrm{m}^{-2} \mathrm{~s}^{-1}$. During night-time, when the assimilation is set to zero, the modelled respiration flux plus the $\mathrm{CO}_{2}$ concentration gradient in time of each box $\left(\mathrm{CO}_{2}\right.$ storage) is identical to the measured values of the eddy covariance measurements, which is a simple consequence of the conservation of mass in the model equations. Figure 8 (solid lines) presents the cumulated gross fluxes during the model run of $72 \mathrm{~h}$. The one-dimensional (1-D) box model predicts cumulated assimilation fluxes of $3.6 \mathrm{~mol} \mathrm{~m}^{-2}$ after $72 \mathrm{~h}$. By combination of transport and vegetation isotope exchange processes, the 1-D box model is able to separate between assimilation and respiration fluxes. This appears to be trivial, and of course there is no reason to wonder about assimilation being a sink flux to the atmosphere. However, this is the first approach that uses the ${ }^{18} \mathrm{O}$ interaction between $\mathrm{CO}_{2}$ and $\mathrm{H}_{2} \mathrm{O}$ in a closed process/transport model, resulting in reasonable flux numbers.

\subsection{Sensitivity runs}

Assessment of the 1-D isotopic box model output requires a study of the sensitivity on the relevant

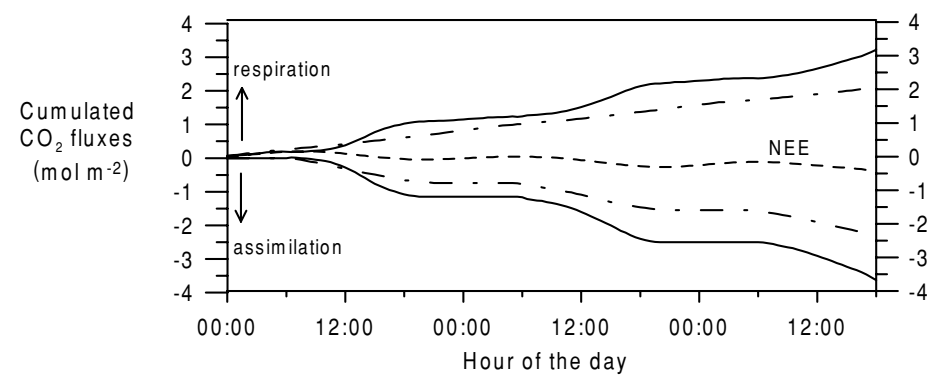

Fig. 8. Cumulated $\mathrm{CO}_{2}$ fluxes. Standard simulation (solid lines), Lloyd and Taylor (1994) model (dash-dotted lines), along with the net ecosystem exchange (NEE) flux at the top of the canopy (dashed line).

Tellus 54B (2002), 5 
parameters controlling the respective processes. In principle, the model depends on the parameterisation of (1) the transport, (2) the isotopic composition of the interacting reservoirs and (3) the associated fractionations and discriminations.

5.2.1. ${ }^{222} R n$ transport calibration. The only variable that can change the model transport patterns between the bottom canopy boxes is the ${ }^{222} \mathrm{Rn}$ soil exhalation flux. Variation in the atmospheric $\mathrm{CO}_{2}$ mixing ratio and ${ }^{222} \mathrm{Rn}$ activity vertical gradients within the measurement uncertainties does not significantly change the model transport patterns. In the model, the ${ }^{222} \mathrm{Rn}$ soil flux is assumed to be constant in time and space. As the soil exhalation transect measurements show large spatial variation, correlated to soil water content (Levin et al., 2002), the mean value of $10 \mathrm{~Bq}$ $\mathrm{m}^{-2} \mathrm{~h}^{-1}$ used in the standard simulation needs not to be the actual soil ${ }^{222} \mathrm{Rn}$ influx to box 1 . Furthermore, the spatial heterogeneity of the soil ${ }^{222} \mathrm{Rn}$ flux leads to changing influxes to box 1 , due to potentially changing footprint areas around the tower measurement site when the wind direction changes. The soil type directly below the tower showed a mean soil flux of $4.6 \pm 0.9 \mathrm{~Bq} \mathrm{~m}^{-2} \mathrm{~h}^{-1}$, whereas the overall soil type weighted footprint mean is $24.0 \pm 9.7 \mathrm{~Bq} \mathrm{~m}^{-2} \mathrm{~h}^{-1}$ in July 1999. Therefore, the model was tested for its sensitivity to the soil influx $F_{\text {soil }}(\mathrm{Rn})$ in eq. (4) for a range from 2 to $20 \mathrm{~Bq} \mathrm{~m}^{-2} \mathrm{~h}^{-1}$, assumed to be relevant for the tower measurement site. Figure 9a presents the results of this test via the modelled cumulated gross fluxes. Variation of $F_{\text {soil }}(\mathrm{Rn})$ between 2 and $20 \mathrm{~Bq} \mathrm{~m}^{-2}$ $\mathrm{h}^{-1}$ leads to deviations from the standard simulation between $-8 \%$ and $+16 \%$ for the resulting cumulative gross fluxes. Lower $F_{\text {soil }}(\mathrm{Rn})$ leads to lower gross assimilation fluxes of the system. This is due to the changing intra-canopy transport parameterisation [eq. (4)], i.e. a lower $F_{\text {soil }}(\mathrm{Rn})$ yields a lower exchange coefficient $K_{12}$ which again decreases the $\mathrm{CO}_{2}$ flux from box 1 to box 2, $F_{12}\left(\mathrm{CO}_{2}\right)$ [eq. (9)]. This causes a higher assimilation flux in box 1 and a lower assimilation flux in box 2 . As the assimilation activity of the system is controlled by box 2 , the overall assimilation flux is decreasing.

5.2.2. Variations of isotopic composition and discriminations. The model is largely driven by the respective ${ }^{18} \mathrm{O}$ isotopic compositions of the $\mathrm{CO}_{2}$ and $\mathrm{H}_{2} \mathrm{O}$ reservoirs. Here it is assumed that the flask measurements deliver a precise characterisation of the $\mathrm{CO}_{2}$ mixing ratio and isotopic composition of the respective box because the model sensitivity tests within the measurement uncertainties showed no significant devia- tions from the standard simulation. Within the equation system (10)-(13) the sensitive terms are then given by the ${ }^{18} \mathrm{O}$ isotopic composition of leaves and soil, respectively. Together with the parameterisation of the associated fractionation and discriminations, sensitivity is tested for the overall leaf discrimination and the overall soil "discrimination".

5.2.2.1. Overall leaf discrimination, $\Delta_{\text {leaves: }}$ The overall leaf discrimination, $\Delta_{\text {leaves}}$, is itself a function of (1) the $\delta^{18} \mathrm{O}$ isotopic composition of leaf water, $\delta_{\text {leaf }},(2)$ the ${ }^{18} \mathrm{O}-\mathrm{CO}_{2}$ diffusion fractionation from the ecosystem air to the site of carboxylation, $\varepsilon_{\text {leaf }}$, and (3) the parameterisation of the chloroplast $\mathrm{CO}_{2}$ concentration, $c_{\mathrm{c}}$. Therefore, the model sensitivity on these terms is investigated. Exemplary, the basic answer of $\Delta_{\text {leaves }}$ on varying parameterisations is shown for box 2 and the overall model sensitivity is presented via the cumulated gross fluxes.

$\delta^{18} O$ isotopic composition of leaf water, $\delta_{\text {leaf }}$ : The leaf water isotopic compositions used in the model, are mean values of the measured bulk leaf water that were attributed to the respective box. One can easily imagine that these values need not to be representative for all leaves in the footprint that interacted with the observed $\mathrm{CO}_{2}$. This spatial heterogeneity in the signal is a serious problem. Furthermore, the isotopic composition of the leaf water is also expected to be enriched at the site of evaporation, and huge gradients of $\delta^{18} \mathrm{O}$ are observed within the leaf itself (Bariac et al., 1990). Consequently, the measurement of the bulk leaf water may underestimate the enrichment of the interacting leaf water $\delta^{18} \mathrm{O}$.

An alternative approach to derive the leaf-water $\delta^{18} \mathrm{O}$ is to apply the steady-state leaf transpiration model of Craig and Gordon (1965). The Craig and Gordon model calculates the isotopic composition of leaf water according to:

$\delta_{\text {leaf }}=\varepsilon_{\text {liq-vap }}+(1-\mathrm{rh})\left(\delta_{\text {root }}-\varepsilon_{\text {kin }}\right)+\operatorname{rh} \delta_{\text {vap }}$.

In our study the relative humidity, rh, is assumed to be the measured relative humidity within the ecosystem. $\delta_{\text {root }}$, representing the $\delta^{18} \mathrm{O}$ of root $\mathrm{H}_{2} \mathrm{O}$ taken up from the soil water, was also measured, as well as the $\delta^{18} \mathrm{O}$ of water vapour outside the leaf, $\delta_{\text {vap }}$. The equilibrium fractionation of $\mathrm{H}_{2}{ }^{18} \mathrm{O}$ for the liquidvapour phase transition $\varepsilon_{\text {liq-vap }}$ is well known and varies with temperature (Majoube, 1971). Only the kinetic fractionation of $\mathrm{H}_{2}{ }^{18} \mathrm{O}$ for the diffusion of water vapour across the sub-stomata cavity via the leaf boundary layer to the ecosystem air, $\varepsilon_{\text {kin }}$, is not well 


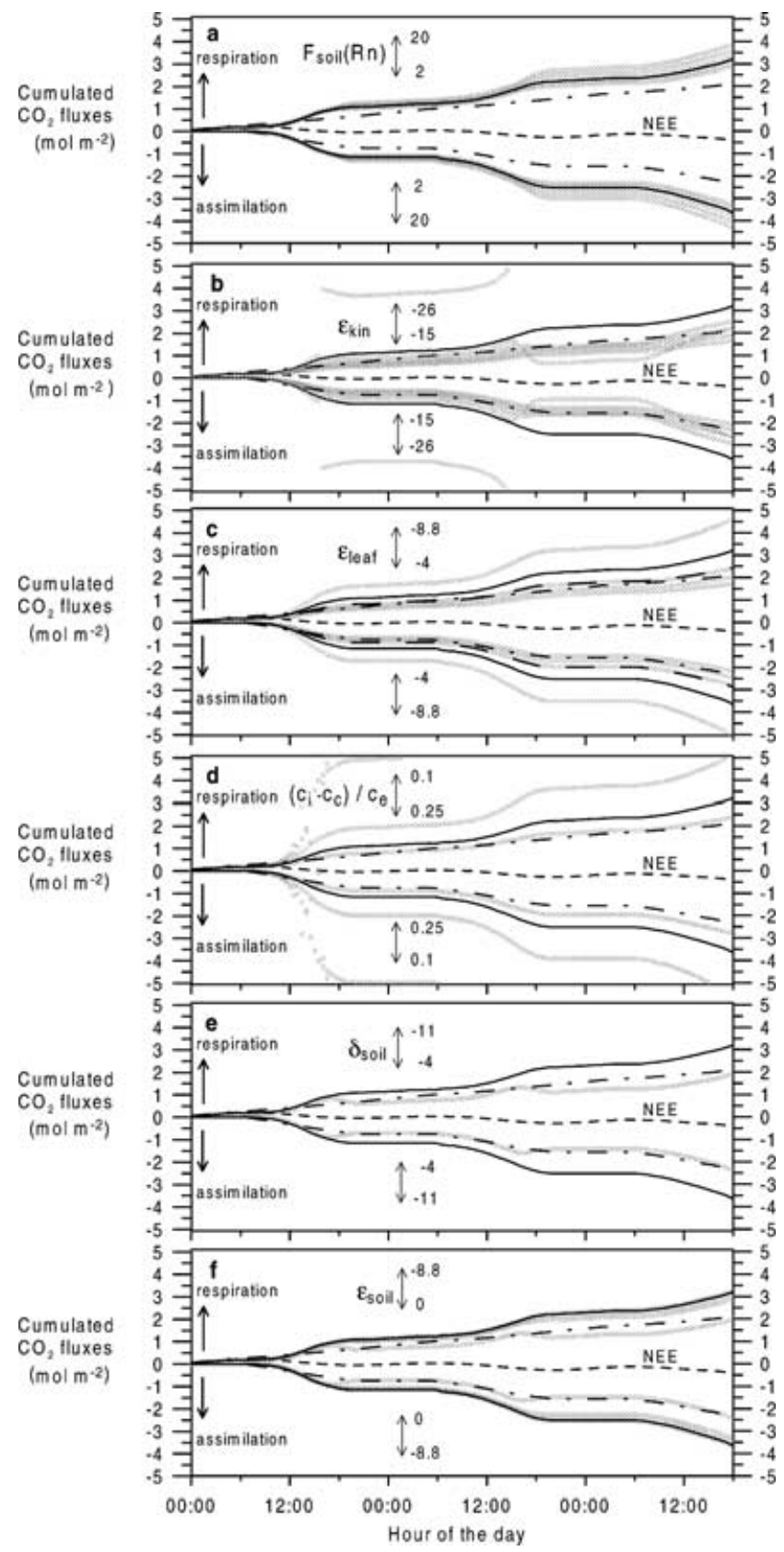

Fig. 9. Sensitivity runs for varying the soil exhalation rate $F_{\text {soil }}(\mathrm{Rn})$ (a), the kinetic fractionation of $\mathrm{H}_{2}{ }^{18} \mathrm{O}$ for the diffusion of water vapour, $\varepsilon_{\text {kin }}(\mathrm{b})$, the effective diffusion fractionation of $\mathrm{C}^{16} \mathrm{O}^{18} \mathrm{O}$ from the ecosystem to the site of carboxylation, $\varepsilon_{\text {leaf }}$ (the run using the parameterised $\varepsilon_{\text {leaf }}$ (see text) is represented by the long-dashed line) (c), the parameterisation of $\left(c_{\mathrm{i}}-c_{\mathrm{c}}\right) / c_{\mathrm{e}}(\mathrm{d})$, the soil water $\delta^{18} \mathrm{O}-\mathrm{H}_{2} \mathrm{O}$ composition, $\delta_{\text {soil }}(\mathrm{e})$, and the effective soil fractionation against $\mathrm{C}^{16} \mathrm{O}^{18} \mathrm{O}$ during diffusion through the soil to the ecosystem atmosphere, $\varepsilon_{\text {soil }}$ (f). NEE derived gross fluxes following the Lloyd and Taylor model (Milyukova et al., 2002) are given as the dash-dotted lines, along with the NEE at the top of the canopy (dashed lines). The standard simulation is represented by the solid lines. 


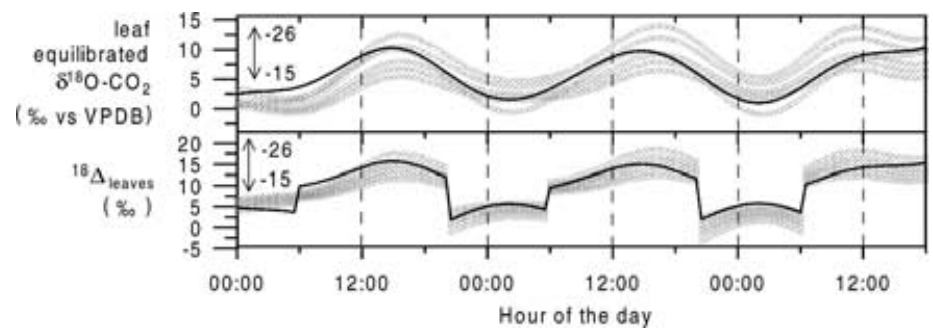

Fig. 10. Upper panel: $\delta_{\text {leaf }}$ values equilibrated with $\delta^{18} \mathrm{O}-\mathrm{H}_{2} \mathrm{O}$ of leaf water calculated via Craig and Gordon with varying $\varepsilon_{\text {kin }}$ from $-26 \%$ to $-15 \%$. Lower panel: resulting variation in $\Delta_{\text {leaves }}$. Solid lines: standard simulation using measured bulk leaf water $\delta^{18} \mathrm{O}$, symbols: test runs. Note that night-time values are not relevant to the model, as assimilation is set to zero.

parameterised. This value depends on the turbulent boundary conditions at the leaf surface and may vary from values for turbulent conditions, about $-15 \%$, to the value for molecular diffusive conditions at the leaf surface of $-26 \%$ (Merlivat, 1978). Figure 10 shows the results of the Craig and Gordon model for the $\delta^{18} \mathrm{O}$ signature of $\mathrm{CO}_{2}$ in isotopic equilibrium with leaf water (calculated on the basis of observed $\delta_{\text {vap }}$ and rh). The diurnal cycle of the leaf $\delta^{18} \mathrm{O}-\mathrm{CO}_{2}$ shows very similar variation as the values derived from equilibration (at the same temperature) with the measured bulk leaf water. Variation in $\varepsilon_{\text {kin }}$ between $-15 \%$ and $-26 \%$ o leads to the expected variation of the modelled leaf $\delta^{18} \mathrm{O}$ $\mathrm{CO}_{2}$. For larger fractionations, i.e. under molecular diffusive leaf boundary conditions, the Craig and Gordon model predicts up to $5 \%$ more enriched leaf water $\delta^{18} \mathrm{O}$ values than the measured bulk derived values. In this case $\Delta_{\text {leaves }}$ also shows higher values, which can easily be seen from eq. (14) and Fig. 10 (lower panel). Figure $9 \mathrm{~b}$ shows the sensitivity of the model on $\varepsilon_{\text {kin }}$ (and on the accompanied variation in leaf water $\delta^{18} \mathrm{O}$ and $\left.\Delta_{\text {leaves }}\right)$ on the overall cumulated fluxes. In principle, the model output cumulated fluxes stay quite stable for smaller $\Delta_{\text {leaves }}$ discriminations, i.e. more depleted leaf water $\delta^{18} \mathrm{O}-\mathrm{H}_{2} \mathrm{O}$ and respective $\varepsilon_{\text {kin }}$ values larger than $-22 \%$ o. In this case the cumulated fluxes are smaller than the fluxes obtained for the standard simulation. Basically, for $\Delta_{\text {leaves }}$ values exceeding those of the standard simulation (by only $3 \%$ ) the model output diverges. This is due to the fact that within the substitution performed in the equation system (10)-(13) the assimilation flux is proportional to $1 /\left(\Delta_{\text {leaves }}+\Delta_{\text {soils }}\right)$. With $\Delta_{\text {soils }}$ values of about $-19 \%$ during day-time, increasing $\Delta_{\text {leaves }}$ values lead the denominator in the assimilation equation to converge against zero, and the assimilation flux diverges immediately. Therefore, the model is highly sensitive on the parameterisation of $\Delta_{\text {leaves }}$.
Concerning implementation of the Craig and Gordon equation into the box model, this would require steady-state transpiration conditions. These are usually not observed, especially during the strong diurnal variation of the transpiration rate (e.g. Harwood et al., 1998). However, the Craig and Gordon equation is largely controlled by the relative humidity and also influenced by the water vapour isotopic composition. Both are hard to determine on the leaf scale under natural conditions, therefore a precise determination of the leaf water ${ }^{18} \mathrm{O}$ is very difficult.

$C^{16} O^{18} O$ diffusion fractionation, $\varepsilon_{\text {leaf }}$ : The second parameter that controls the variation in $\Delta_{\text {leaves }}$ is the $\mathrm{C}^{16} \mathrm{O}^{18} \mathrm{O}$ diffusion fractionation from the ecosystem air to the site of carboxylation, $\varepsilon_{\text {leaf }}$. In the standard simulation, the effective leaf discrimination is assumed to be constant in time, and the value of $-7.4 \%$ o given by Farquhar et al. (1993) was used. However, as mentioned before, this is a mean value, averaging over three involved fractionation processes, namely the fractionation for molecular diffusion through the stomata $\left(\varepsilon_{\mathrm{d}}=-8.8 \%\right.$ ), the fractionation for diffusion through the leaf boundary layer $\left(\varepsilon_{\mathrm{b}}=-5.8 \%\right.$ o $)$ and the fractionation summarising an equilibrium dissolution effect and diffusion fractionation in solution at the mesophyll cell walls $\left(\varepsilon_{\mathrm{w}}=-0.8 \%\right.$ o). Therefore, the model was tested for variations of $\varepsilon_{\text {leaf }}$ between -8.8 and $-4 \%$. Furthermore, a simulation run was performed that includes the parameterisation of $\varepsilon_{\text {leaf }}$ via the weighted $\mathrm{CO}_{2}$ gradients from the ecosystem air to the site of carboxylation in the chloroplasts [eq. (16)] yielding values between -5.8 and $-6.1 \%$ o. These numbers are up to $1.5 \%$ o smaller than the value for the mean fractionation factor of $-7.4 \%$ given by Farquhar et al. (1993). The parameterisation according to eq. (16) therefore suggests a higher influence of the associated fractionation steps connected with smaller fractionations, which are the molecular 
diffusion through the leaf boundary layer, $\varepsilon_{\mathrm{b}}$, and the fractionation summarising an equilibrium dissolution effect and diffusion fractionation in solution at the mesophyll cell walls, $\varepsilon_{\mathrm{w}}$. Just like the kinetic fractionation of water vapour in the Craig and Gordon equation, the leaf boundary conditions are likely to influence the overall $\varepsilon_{\text {leaf }}$. As the $\mathrm{CO}_{2}$ gradients within the leaves, especially from the inner cellular spaces to the site of carboxylation, are poorly understood, the parameterisation of $\varepsilon_{\mathrm{w}}$ in eq. (16) remains shaky. The impact of smaller $\varepsilon_{\text {leaf }}$ numbers (to the mean absolute value) is a decrease of $\Delta_{\text {leaves }}$. The impact of $\varepsilon_{\text {leaf }}$ (and of the accompanied variation in $\Delta_{\text {leaves }}$ ) on the resulting gross fluxes, as discussed before, is shown in Fig. 9c. Here, smaller fractionation will lead to smaller cumulative fluxes compared to the standard run. The run using the parameterised $\varepsilon_{\text {leaf }}$ (long dashes in Fig. 9c) shows a similar behaviour to the estimates of the NEEderived fluxes (dashed-dotted line in Fig. 9, see Section 6). Assuming a maximum diffusion fractionation of only $-8.8 \%$ o leads to about $50 \%$ higher gross flux results.

Chloroplast $\mathrm{CO}_{2}$ concentration, $c_{\mathrm{c}}$ : The third parameter that controls the variation in $\Delta_{\text {leaves }}$ is the parameterisation of the chloroplast $\mathrm{CO}_{2}$ concentration, $c_{\mathrm{c}}$ (or, as mentioned before, at the chloroplast surface). After modelling the sub-stomata cavity $\mathrm{CO}_{2}$ concentration $c_{\mathrm{i}}$ by using the ${ }^{13} \mathrm{C} /{ }^{12} \mathrm{C}$ ratios of ecosystem air and plant cellulose in eq. (15), the chloroplast $\mathrm{CO}_{2}$ concentration has to be determined. As discussed before, the present knowledge of how to parameterise $c_{\mathrm{c}}$ ranges from $\left(c_{\mathrm{i}}-c_{\mathrm{c}}\right) / c_{\mathrm{e}} \sim 0.1$ to $\left(c_{\mathrm{i}}-c_{\mathrm{c}}\right) / c_{\mathrm{e}} \sim 0.2$. The resulting range of $c_{\mathrm{c}} / c_{\mathrm{e}}$ ratios shows values between 0.4 and 0.6. For $c_{\mathrm{c}}=c_{\mathrm{i}}-0.1 c_{\mathrm{e}}, \Delta_{\text {leaves }}$ reaches values of about $20 \%$ which, for reasons discussed earlier, delivers very high assimilation fluxes. Note here that during night, when the assimilation term in the model is set to zero, $\Delta_{\text {leaves }}$ does not influence the flux calculation. As mentioned before, during the night the leaf internal $\mathrm{CO}_{2}$ concentration can increase up to several thousand $\mathrm{ppm}$, and the $c_{\mathrm{c}} /\left(c_{\mathrm{e}}-c_{\mathrm{c}}\right)$ term in eq. (14) converges to -1 .

The basic features of the model runs presented in Fig. $9 \mathrm{~d}$, where $\left(c_{\mathrm{i}}-c_{\mathrm{c}}\right) / c_{\mathrm{e}}$ is varied between 0.1 and 0.25 , is that estimating $\mathrm{CO}_{2}$ gradients between the leaf surface and the site of carboxylation that are too low can totally destroy the model output. The $c_{\mathrm{c}}$ parameterisation $\left(c_{\mathrm{i}}-c_{\mathrm{c}}\right) / c_{\mathrm{e}} \sim 0.15$ leads to about $100 \%$ higher gross fluxes than the setting of the standard simulation, using $\left(c_{\mathrm{i}}-c_{\mathrm{c}}\right) / c_{\mathrm{e}} \sim 0.2$. Therefore, a knowledge of the leaf internal $\mathrm{CO}_{2}$ concentration gradients is, be- sides the parameterisation of the leaf discrimination, $\varepsilon_{\text {leaf }}$, and the determination of the leaf water isotopic composition, $\delta_{\text {leaves }}$, a limiting factor on using the potential of ${ }^{18} \mathrm{O}$ in carbon cycling studies.

5.2.2.2. Overall soil "discrimination", $\Delta_{\text {soil }}$ : As mentioned above, beside the overall leaf discrimination, $\Delta_{\text {leaves }}$, the last sensitive term to discuss within the equation system (10)-(13) is the overall soil "discrimination" $\Delta_{\text {soil }}$ in box 1 . The overall soil discrimination itself, is a function of (1) the isotopic composition of the soil water, $\delta_{\text {soil }}$, and (2) the value of the soil $\mathrm{C}^{16} \mathrm{O}^{18} \mathrm{O}$ diffusion fractionation from the soil to the ecosystem air, $\varepsilon_{\text {soil }}$. Therefore, the model sensitivity of these terms and the basic answer of $\Delta_{\text {soil }}$ on varying parameterisations is investigated.

Variation in soil water, $\delta_{\text {soil }}$ : As the soil water could potentially become significantly enriched in $\delta^{18} \mathrm{O}-\mathrm{H}_{2} \mathrm{O}$ near the soil surface through evaporation, this enrichment could result in an underestimation of the soil $\delta^{18} \mathrm{O}-\mathrm{CO}_{2}$. Miller et al. (1999) show that as first good approximation, one should take the soil water value at $15 \mathrm{~cm}$ depth. Hence, the effect of soil water enrichment at the soil surface should not be too pronounced. Alternatively, it can be assumed that the stem isotopic composition of the mosses and blueberries reflects the isotopic composition of water in the top soil layer (J. Lloyd, personal communication). This is due to the fact that these understory plants are supplied by water near the surface. Furthermore, the stem isotopic composition represents an integrated value of the upper soil water in space and time. The effect of replacing the measured $\delta^{18} \mathrm{O}-\mathrm{H}_{2} \mathrm{O}$ of soil water of about $-11 \%$ by the isotopic composition of the understory stems $\delta^{18} \mathrm{O}-\mathrm{H}_{2} \mathrm{O}$ of about $-4 \%$ is presented in Fig. 9e. $\Delta_{\text {soil }}$ is proportional to the $\delta^{18} \mathrm{O}-\mathrm{CO}_{2}$ value. Therefore, more enriched soil water $\delta^{18} \mathrm{O}$ leads to higher overall soil discriminations $\Delta_{\text {soil }}$. As a consequence of the $1 /\left(\Delta_{\text {leaves }}+\Delta_{\text {soils }}\right)$ term in the assimilation substitution equation, the denominator increases and assimilation fluxes decrease. The resulting gross fluxes of this test in Fig. 9e show a good agreement with the NEE-derived cumulated fluxes of about $2.5 \mathrm{~mol} \mathrm{~m}^{-2}$ assimilation after $72 \mathrm{~h}$.

Effective soil fractionation against $C^{16} O^{18} O, \varepsilon_{\text {soil }}$ : The second potentially variable term that controls the overall soil "discrimination", $\Delta_{\text {soils }}$, is the effective soil fractionation against $\mathrm{C}^{16} \mathrm{O}^{18} \mathrm{O}$ during diffusion through the soil to the ecosystem atmosphere. During diffusion through the soil kinetic fractionation is theoretically limited to a maximum value of $\varepsilon_{\text {soil }}=-8.8 \%$ o in case of purely molecular diffusion of $\mathrm{CO}_{2}$. However, 
as turbulent diffusion does not fractionate, and the top few centimetres of the soil may be exposed to small eddy turbulence of the atmosphere, effective fractionation may be smaller and is varied in the sensitivity run between $0 \%$ and the maximum value of $-8.8 \%$ o. In principle, the influence of decreasing the effective soil fractionation (by an absolute value) is the same as assuming more enriched soil water in the equations. In a similar way, $\Delta_{\text {soils }}$ increases with the consequence of smaller resulting gross fluxes. Figure $9 \mathrm{f}$ presents the impact on variation of $\varepsilon_{\text {soil }}$ on the cumulative gross fluxes, and it can be seen that the model is not very sensitive to these variations.

\section{Discussion and comparison with concurrent methods}

The 1-D box model output fluxes are compared with concurrently estimated gross fluxes based on the same eddy correlation data as used in this study (dashed and dashed-dotted lines in Figs. 7-9): Milyukova et al. (2002) applied the model developed by Lloyd and Taylor (1994), using mean night-time $\mathrm{CO}_{2}$ total ecosystem respiration fluxes and air and soil temperatures obtained on a daily basis. Basically, they extrapolate an empirical respiration function derived from the night-time ecosystem respiration and its dependency on the soil and air temperature to the daytime. By introducing a coefficient that allows for a joint effect of both soil temperature and air temperature on the ecosystem respiration rate, they partitioned the overall respiration flux into $71 \%$ soil respiration and 29\% stem and foliar respiration (best fit). A shortcoming of the eddy covariance technique is its dependency on a sufficient turbulence strength. Therefore, Milyukova et al. (2002) recalculated all night-time fluxes for situations with a friction velocity $u^{*}<0.35 \mathrm{~m} \mathrm{~s}^{-1}$ by regression. During the period simulated with the model a mean day-time friction velocity of $u^{*}=0.54 \pm 0.16 \mathrm{~m} \mathrm{~s}^{-1}$ and a mean night-time friction velocity of $u^{*}=0.31 \pm 0.13 \mathrm{~m} \mathrm{~s}^{-1}$ was measured. In particular, the second night showed very low $\mathrm{u}^{*}$ values with a mean of $0.21 \pm 0.07 \mathrm{~m}$ $\mathrm{s}^{-1}$. Therefore, for this night all data were calculated by regression, and the smoothed measured NEE (Fig. 7, lowest panel) deviates from the results of Milyukova et al. (2002). To compare the 1-D box model with this approach, the same $R_{\mathrm{a}} / R_{\text {soil }}$ ratio was chosen in the parameterisation of the isotope balance in box 1.

\subsection{Comparison of the gross fluxes and $Q_{10}$ values}

During night-time, when assimilation is set to zero, the modelled respiration flux plus the storage in each box is identical to the measured values of the eddy covariance measurements, which is a simple consequence of the conservation of mass in the model equations. During day-time the model predicts assimilation fluxes with a shape similar to PAR, resulting in maximum values between 40 and $50 \mu \mathrm{mol} \mathrm{m}^{-2} \mathrm{~s}^{-1}$ around noon and respiration is increasing up to about 30 to $40 \mu \mathrm{mol} \mathrm{m} \mathrm{m}^{-2} \mathrm{~s}^{-1}$. The mean day-time ambient air temperature during the simulation period was $19.8 \pm$ $2.7^{\circ} \mathrm{C}$ and the mean night-time temperature $14.9 \pm$ $2{ }^{\circ} \mathrm{C}$, whereas the soil temperature did not vary significantly, with a mean of $13.3 \pm 0.2{ }^{\circ} \mathrm{C}$. Compared to the night-time respiration flux with values of about $10 \mu \mathrm{mol} \mathrm{m} \mathrm{m}^{-2} \mathrm{~s}^{-1}$ this would imply a $Q_{10}$ value of about 7 , if related only on ambient air temperature. This $Q_{10}$ value relates to the flux weighted sum of all processes yielding ecosystem respiration, that is tree plus root respiration and soil heterotrophic respiration. Traditionally ecosystem process models use a $Q_{10}$ of about 2 (Reich et al., 1991), even though respiration studies suggest a mean $Q_{10}$ around 2.5 (Reich and Schlesinger, 1992). Usually $Q_{10}$ values are related to soil respiration only, and a large variation between local site studies is observed. Besides $Q_{10}$ values of 2 , values can range site-specifically from 3.5 for bulk soil in a mixed temperate forest (Boone et al., 1998) to 11.7 for a floodland white spruce forest (Gulledge and Schimel, 2000). Respiration of living cells in foliage, woody tissue and roots can consume more than $60 \%$ of the carbon fixed in photosynthesis (Edwards et al., 1980), but information on respiration rates, and especially ecosystem-level flux estimates, is sparse (Ryan et al., 1994). Leaf-scale measurements of foliage respiration suggest $Q_{10}$ values around 2.3 (Hubbard et al., 1995).

There is a significant difference between the 1-D box model and the eddy correlation derived gross fluxes. Whereas the 1-D isotope box model predicts assimilation maxima of about $40 \mu \mathrm{mol} \mathrm{m} \mathrm{m}^{-2} \mathrm{~s}^{-1}$, the respiration extrapolation yields maximum values of about $20 \mu \mathrm{mol} \mathrm{m} \mathrm{m}^{-2} \mathrm{~s}^{-1}$. The 1-D box model yields a mean night-time respiration flux of $5.7 \pm 2.8 \mu \mathrm{mol}$ $\mathrm{m}^{-2} \mathrm{~s}^{-1}$, a factor of 1.7 smaller than the NEE derived flux of $9.5 \pm 2.9 \mu \mathrm{mol} \mathrm{m} \mathrm{m}^{-2} \mathrm{~s}^{-1}$ (Milyukova et al., 2002). However, within the $1 \sigma$ standard deviation, both total ecosystem respiration fluxes are comparable. Comparison with direct soil chamber 
measurements [mean night-time respiration $6.4 \pm 1.7$ $\mu \mathrm{mol} \mathrm{m}{ }^{-2} \mathrm{~s}^{-1}$ (Langendörfer, 2001)] indicates an underestimation of the 1-D box model derived respiration fluxes because the soil chamber does not account for above-ground respiration fluxes. However, as the soil $\mathrm{CO}_{2}$ respiration represents the major part of the overall ecosystem respiration (about 70\%), night-time respiration fluxes of all approaches are consistent within a $1 \sigma$ uncertainty range. Significant differences between the results of the respective day-time respiration fluxes are observed. Compared to night-time, the mean daytime respiration of the 1-D box model increases by a factor of 3.4 to $19.6 \pm 9.5 \mu \mathrm{mol} \mathrm{m} \mathrm{m}^{-2} \mathrm{~s}^{-1}$ while the NEE derived day-time fluxes decrease slightly by about $14 \%$. The chamber-derived soil respiration increases by a factor of 1.5 to $9.4 \pm 5.2 \mu \mathrm{mol} \mathrm{m}^{-2} \mathrm{~s}^{-1}$. As mentioned before, in principle an increase of overall ecosystem respiration is expected. With an observed average air temperature increase from about $15^{\circ} \mathrm{C}$ during night to a day-time mean of about $20^{\circ} \mathrm{C}$, this would imply $Q_{10}$ values of 6.8 for the 1-D box model results, about 1 for the NEE approach and 1.5 for the direct soil measurements, if related to ambient air temperature. However, the direct soil flux should to a higher extent depend on the quite stable temperature of the top soil layer (minimum $13{ }^{\circ} \mathrm{C}$, maximum $13.7^{\circ} \mathrm{C}$ ), and therefore a smaller diurnal variation is expected. Here, the standard simulation of the 1-D box model could overestimate the temperature dependence of the overall ecosystem respiration flux.

\subsection{Comparison of the cumulated gross fluxes}

The basic differences of the 1-D box model and the NEE approach can also be manifested by inspection of the cumulated fluxes for the model run over $72 \mathrm{~h}$ (see Figs. 8 and 9a-f). These figures mirror the cumulated gross fluxes and the net ecosystem $\mathrm{CO}_{2}$ flux, and illustrate the principal differences in the features of both approaches discussed before. The 1-D box model overall cumulative respiration slope is observed to increase mainly during day-time, whereas the NEE derived cumulative respiration is increasing nearly constantly during day and night. Both cumulative assimilation curves show an increasing negative gradient with the onset of photosynthetic activity. After the 3 day standard simulation run, the differences in the cumulated assimilation fluxes end up as $3.6 \mathrm{~mol}$ $\mathrm{m}^{-2}$ for the 1-D box model and $2.3 \mathrm{~mol} \mathrm{~m}^{-2}$ for the NEE derived cumulative assimilation. Due to conservation of mass, this principal difference between the approaches is also observed for the cumulative respiration fluxes.

\section{Summary and conclusions}

The 1-D isotopic box model set-up developed here is in principle capable of calculating reasonable numbers for the gross fluxes in the investigated ecosystem. It is the first approach that combines field measurements with a closed model set-up, providing separate ecosystem $\mathrm{CO}_{2}$ gross fluxes. There has been only one study up to now combining ${ }^{18} \mathrm{O}$ isotopic processes with measured transport; however, it could not predict the correct direction of the gross fluxes (Bowling et al., 1999). Bowling et al. combined NEE measurements with flask measurements within the canopy to derive the exchange of isotopes. The processing of the respective discriminations was basically performed with the same equations which were applied here, and with measurements of bulk leaf water. However, this study assumed the isotopic signal of respiration, derived from an overall Keeling plot, to be constant with time. Furthermore, the ecosystem was treated as one box, not considering vertical gradients in leaf water $\delta^{18} \mathrm{O}-\mathrm{H}_{2} \mathrm{O}$ within the canopy. The study by Yakir and Wang (1996), which first used the described approach, is conceptually different because the authors calculate/estimate the transport while Bowling et al. and this study really measure it (here via ${ }^{222} \mathrm{Rn}$ ).

With the input data set that was measured in the field, the output fluxes are comparable with concurrently estimated gross fluxes derived via the NEE respiration flux extrapolation method. However, the model is sensitive to the chosen parameterisation of transport, the isotopic composition of the involved reservoirs and to the associated fractionations and discriminations, respectively. This results in an overall uncertainty of the model, which is in the order of a factor of two. Within the known range of these crucial parameters from other experiments described in the literature, which were mainly obtained from small-scale measurements under laboratory conditions, the model is largely stable. This is especially true with respect to the ${ }^{222} \mathrm{Rn}$ calibrated intra-canopy transport characterisation. Limiting to the model applicability, however, is the existence of adequate vertical gradients of the ${ }^{222} \mathrm{Rn}$ activity within the canopy. As derived from the sensitivity studies the most crucial parameter is the determination of the overall leaf discrimination, $\Delta_{\text {leaves }}$. Here the setting of the chloroplast $\mathrm{CO}_{2}$ concentration 
exhibits the strongest control, besides the variation of $\delta^{18} \mathrm{O}-\mathrm{H}_{2} \mathrm{O}$ of leaf water. Up to now, there are only few studies dealing with measurements of leaf $\mathrm{CO}_{2}$ conductance to determine the overall leaf discrimination (Gillon and Yakir, 2000). Therefore, effort should be invested in leaf-scale investigations in order to parameterise properly the critical leaf internal $\mathrm{CO}_{2}$ gradients for a wide range of different species and environmental/hydrological conditions. Besides the respective parameterisations discussed above, the principal restriction of modelling ${ }^{18} \mathrm{O}$ in canopy ecosystems is spatial heterogeneity in the $\delta^{18} \mathrm{O}-\mathrm{CO}_{2}$ signal. The model assumes horizontal homogeneity of the distribution of the isotopic signatures. Also, in the vertical direction, this approach assumes mean measured values to be representative for each box. Therefore, any spatial variation may seriously influence the output of the model.

In the context of global ${ }^{18} \mathrm{O}$ models, where usually monthly means of $\Delta_{\text {leaves }}$ are calculated, the parameterisation of the chloroplast concentration is also essential. Errors of the global model in the major parameters, the $\delta^{18} \mathrm{O}$ of precipitation, leaf water $\delta^{18} \mathrm{O}$ enrichment and the overall leaf discrimination, need to be better quantified (Ciais et al., 1997a; Peylin et al., 1999). However, to compare global models with local measurements is still extremely difficult (if not impossible), as the spatial resolution (horizontal: $7.5^{\circ} \times 7.5^{\circ}$; vertical: nine levels) of these global models is too coarse to take into account small scale structures. Therefore, to use $\delta^{18} \mathrm{O}$ as a $\mathrm{CO}_{2}$ gross flux tracer in global models, the results of the presented local 1-D box model have to be tested and extended to the regional scale. Via subsequent upscaling of the models, a nested $\delta^{18} \mathrm{O}$ model hierarchy should provide further insight to site and species specific vegetation effects.

\section{Acknowledgements}

All the EUROSIBERIAN CARBONFLUX colleagues who made this study possible with their respective engagement are gratefully acknowledged. Special thanks are due to our Russian colleagues Natalja Vygodskaya, Igor Nepomniachii, Andrej Varlagin, Andrej Sogachev, Maxim Panfyorov, Konstantin Sidorov, Daniel Kozlov, Michael Puzachenko and Anatoly "Tolja" Bychkov, who made this fieldstudy possible and contributed over the complete spectrum of questions involved with an invaluable enthusiasm. Rolf Neubert, Sebastien Lafont, Christine Bourg, Pierre Friedlingstein and Michel Ramonet did a great job during the intensive campaign sampling period. We are very grateful to Christel Facklam and Renate Heinz, who analysed the flask samples in the Heidelberg laboratory. This work was funded through the European Commission under contract no. ENV4-CT97-0491.

\section{REFERENCES}

Bariac, T., Jusserand, C. and Mariotti, A. 1990. Evolution spatio-temporelle de la composition de l'eau dans le continuum sol-plante-atmosphere. Geochim. Cosmochim. Acta 54, 413-424.

Boone, R. D., Nadelhoffer, K. J., Canary, J. D. and Kaye, J. P. 1998. Roots excert a strong influence on the temperature sensitivity of soil respiration. Nature 396, 570-572.

Bousquet, P., Ciais, P., Peylin, P., Ramonet, M. and Monfray, P. 1999. Inverse modelling of annual $\mathrm{CO}_{2}$ sources and sinks 1. Methods and control inversion. J. Geophys. Res. 104, D21, 26 161-26 178.

Bowling, D. R., Baldocchi, D. D. and Monson, R. K. 1999. Partitioning net ecosystem exchange in a Tennesse deciduous forest using stable isotopes of $\mathrm{CO}_{2}$. Global Biogeochem. Cycles 13, 903-922.

Buchmann, N., Brooks, J. R., Flanagan, L. B. and Ehleringer, J. R. 1998. Carbon isotope discrimination of terrestrial ecosystems. In: Stable isotopes: integration of biological ecological and geochemical processes (ed. H. Griffiths). BIOS Scientific Publishers Ltd. 203-221.

Brenninkmeijer, C. A. M., Kraft, P. and Mook, W. G. 1983. Oxygen isotope fractionation between $\mathrm{CO}_{2}$ and $\mathrm{H}_{2} \mathrm{O}$. Isotope Geosci. 1, 181-190.

Ciais, P., Tans, P. P., Trolier, M., White, J. W. C. and Francey, R. J. 1995a. A large Northern Hemisphere terrestrial $\mathrm{CO}_{2}$ sink indicated by the ${ }^{13} \mathrm{C} /{ }^{12} \mathrm{C}$ ratio of atmospheric $\mathrm{CO}_{2}$. Science 269, 1098-1102.

Ciais, P., Tans, P. P., White, J. W. C., Trolier, M., Francey, R. J., Berry, J. A., Randall, D. A., Sellers, P. J., Collatz, G. J. and Schimel, D. S. 1995b. Partitioning of ocean and land uptake of $\mathrm{CO}_{2}$ as inferred by $\delta^{13} \mathrm{C}$ measurements from the NOAA Climate Monitoring and Diagnostics Laboratory Global Air Sampling. J. Geophys. Res. 100, 50515070.

Ciais, P., Denning, A. S., Tans, P. P., Berry, J. A., Randall, D. A., Collatz, G. J., Sellers, P. J., White, J. W. C., Trolier, M., 
Meijer, H. A. J., Francey, R. J., Monfray, P. and Heimann M. 1997a. A three dimensional synthesis study of $\delta^{18} \mathrm{O}$ in atmospheric $\mathrm{CO}_{2}$, Part I: Surface fluxes. J. Geophys. Res. 102, 5857-5872.

Ciais, P., Tans, P. P., Denning, A. S., Francey, R. J., Trolier, M., Meijer, H. A. J., White, J. W. C., Berry, J. A., Randall, D. A., Collatz, G. J., Sellers, P. J., Monfray, P. and Heimann M. 1997b. A three dimensional synthesis study of $\delta^{18} \mathrm{O}$ in atmospheric $\mathrm{CO}_{2}$, Part II: Simulations with the TM2 transport model. J. Geophys. Res. 102, 5873-5883.

Craig, H. and Gordon, L. I. 1965. Deuterium and oxygen-18 variations in the ocean and the marine atmosphere. Cons. Naz. delle Ric., Lab. di Geol. Nucl., Tries, Italy.

Edwards, N. T., Shugart, H. H., McLaughlin, S. B., Harris, W. F. and Reichle, D. E. 1980. Carbon metabolism in terrestrial ecosystems. In: Dynamic properties of forest ecosystems (ed. D. E. Reichle). Cambridge University Press, Cambridge, 499-536.

Fan, S.-M., Gloor, M., Mahlman, J., Pacala, S., Sarmiento, J. L., Takahashi, T. and Tans, P. P. 1998. A large terrestrial sink in North America implied by atmospheric and oceanic carbon dioxide data and models. Science 282, 442-446.

Farquhar, G. D. and Rashke, K. 1978. On the resistance to transpiration of the sites of evaporation within the leaf. Plant Physiol. 61, 1000-1005.

Farquhar, G. F. and Lloyd, J. 1993. Carbon and oxygen isotope effects in the exchange of carbon dioxide between plants and the atmosphere. In: Stable isotopes and plantwater relations (eds. J. R. Ehleringer, A. E. Hall and G. D. Farquhar). Academic Press. Inc., San Diego, California, 47-70.

Farquhar, G. D., O'Leary, M. H. and Berry, J. A. 1982. On the relationship between carbon isotope discrimination and the intercellular carbon dioxide concentration in leaves. Aust. J. Plant Physiol. 9, 121-137.

Farquhar, G. D., Ehleringer, J. R. and Hubick, K. T. 1989. Carbon isotope discrimination and photsynthesis. Ann. Rev Plant Physiol. Plant Mol. Biol. 40, 503-537.

Farquhar, G. F., Lloyd, J., Taylor, J. A., Flanagan, L. B., Syvertsen, J. P., Hubick, K. T., Wong, S. C. and Ehleringer, J. R. 1993. Vegetation effects on the isotope composition of oxygen in atmospheric $\mathrm{CO}_{2}$. Nature 363, 439443.

Flanagan, L. B., Brooks, J. R., Varney, G. T. and Ehleringer, F. R. 1997. Discrimination against $\mathrm{C}^{18} \mathrm{O}^{16} \mathrm{O}$ during photosynthesis and the oxygen isotope ratio of respired $\mathrm{CO}_{2}$ in boreal forest ecosystems. Global Biogeochem. Cycles 11, 83-98.

Francey, R. J. and Tans, P. P. 1987. Latitudinal variation in oxygen-18 of atmospheric $\mathrm{CO}_{2}$. Nature 327, 495-497.

Francey, R. J., Tans P. P., Allison, C. E., Enting, I. G., White, J. W. C. and Trolier, M. 1995. Changes in oceanic and terrestrial carbon uptake since 1982. Nature 373, 326330.

Gemery, P. A., Trolier, M. and White, J. W. C. 1996. Oxygen isotope exchange between carbon dioxide and water following atmospheric sampling using glass flasks. J. Geophys. Res. 101, 14415-14420.
Gillon, J. S. and Yakir, D. 2000. Internal conductance to $\mathrm{CO}_{2}$ diffusion and $\mathrm{C}^{18} \mathrm{OO}$ discrimination in $\mathrm{C} 3$ leaves. Plant Physiol. 123, 201-213.

Greschner, B. 1995. Gaschromatographic measurement of atmospheric carbon dioxide, methane and nitrous oxide in Heidelberg (in German). Thesis Institut für Umweltphysik, University of Heidelberg, Germany.

Gulledge, J. and Schimel, J. P. 2000. Controls on soil carbon dioxide and methane fluxes in a variety of taiga forest stands in interior Alaska. Ecosystems 3, 269-282.

Harwood, K. G., Gillon, J. S., Griffiths, H. and Broadmeadow, M. S. J. 1998. Diurnal variation of $\Delta^{13} \mathrm{CO}_{2}, \Delta \mathrm{C}^{18} \mathrm{O}^{16} \mathrm{O}$ and evaporative site enrichment of $\delta \mathrm{H}_{2}{ }^{18} \mathrm{O}$ in Piper aduncum under field conditions in Trinidad. Plant Cell Env. 21, 269-283.

Hubbard, R. M., Ryan, M. G. and Lukens, D. L. 1995. A simple, battery operated, temperature-controlled cuvette for respiration measurements. Tree Physiol. 15, 175-179.

Kays, W. M. 1966. Convective heat and mass transfer. McGraw-Hill, New York.

Keeling, C. D. 1961. The concentration and isotopic abundances of atmospheric carbon dioxide in rural areas. Geochim. Cosmochim. Acta 24, 277-298.

Langendörfer, U. 2001. Oxygen isotopes as a tracer of biospheric $\mathrm{CO}_{2}$ gross fluxes - a local feasibility study. Ph.D. Thesis University of Heidelberg, Germany.

Levin, I., Born, M., Cuntz, M., Langendörfer, U., Mantsch, S., Naegler, T., Schmidt, M., Varlagin, A., Verclas, S. and Wagenbach, D. 2002. Observation of atmospheric variability and soil exhalation rate of radon-222 at a Russian forest site: Technical approach and deployment for boundary layer studies. Tellus, $\mathbf{5 4 B}$, this issue.

Lloyd, J. and Taylor, J. A. 1994. On the temperature dependence of soil respiration. Funct. Ecol. 8, 315-323.

Lloyd, J., Syrversten, J. P., Kiedemann, P. E. and Farquhar, G. D. 1992. Low conductance for $\mathrm{CO}_{2}$ diffusion from stomata to the sites of carboxylation in leaves of woody species. Plant Cell Environ. 15, 873-899.

Merlivat, L. 1978. Molecular diffusivities of $\mathrm{H}_{2}{ }^{18} \mathrm{O}$ in gases. J. Chem. Phys. 69, 2864-2871.

Majoube, M. 1971. Fractionnement en oxygene-18 et en deuterium entre l'eau et sa vapeur. J. Chim. Phys. 58, 14231436.

Miller, J. B., Yakir, D., White, J. W. C. and Tans, P. P. 1999. Measurement of ${ }^{18} \mathrm{O} /{ }^{16} \mathrm{O}$ in the soil-atmosphere $\mathrm{CO}_{2}$ flux. Global Biochem. Cycles 13, 761-774.

Milyukova, I. M., Kolle, O. E., Varlagin, A. B., Vygodskaya, N. N., Schulze, E.-D. and Lloyd, J. 2002. Carbon balance of a southern taiga spruce stand in European Russia. 2001. Tellus 54B, this issue.

Mook, W. G., Koopmans, M., Carter, A. F. and Keeling, C. D. 1983. Seasonal, latitudinal and secular variations in the abundance and isotopic ratios of atmospheric carbon dioxide. 1. Results from land stations. J. Geophys. Res. 88, 10915-10933.

Neubert, R. 1998. Measurement of the stable isotopomeres of atmospheric carbon dioxide (in German). Ph.D. Thesis University of Heidelberg, Germany. 
Peylin, P., Ciais, P., Denning, A. S., Tans, P. P., Berry, J. A. and White, W. C. 1999. A three-dimensional study of $\delta^{18} \mathrm{O}$ in atmospheric $\mathrm{CO}_{2}$ : contribution of different land ecosystems. Tellus 51B, 642-667.

Ramonet, M., Ciais, P., Nepomniachii, I., Sidorov, K., Neubert, R. E. M., Picard, D., Kazan, V., Biraud, S., Gusti, M., Kolle, O., Langendörfer, U., Schulze, E.-D., and Lloyd, J. 2002. Three years of aircraft based trace gas measurements over the Fyodorovskoye southern taiga forest, 300 $\mathrm{km}$ North-West of Moscow. Tellus 54B, this issue.

Raven, J. A. and Glidewell, S. M. 1981. Physiological processes limiting plant productivity. In: Processes Limiting Photosynthetic Conductance (ed. C. B. Johnson). Butterworths, London, 109-136.

Reich, J. W., Rastetter, E. B., Melillo, D. W., Kicklighter, D. W., Steudler, P. A., Peterson B. J., Grace, A. L., Moore, B. and Vorosmarty, C. J. 1991. Potential net primary production in South Africa. Ecol. Appl. 1, 399-429.

Reich, J. W. and Schlesinger, W. H. 1992. The global carbon dioxide flux in soil respiration and its relationship to vegetation and climate. Tellus 44B, 81-99.
Ryan, M. G., Lindner, S., Vose, J. M. and Hubbard, R. M. 1994. Dark respiration in pines. In: Pine ecosystems (eds. H. L. Gholz, S. Lindner and R. E. McMurtrie). Ecol. Bull, Uppsala, 50-63.

Schimel, D., Enting, I. G., Heimann, M., Wigley, T. M. L., Raynaud, D., Alves, D. and Siegenthaler, U. 1996. $\mathrm{CO}_{2}$ and the carbon cycle. In: Climate Change 1995: the science of climate change (eds. J. T. Houghton, L. G. Meira Filho, B. A. Callander, N. Harris, A. Kattenberg and K. Maskell). Intergovernmental Panel on Climate Change, Cambridge, UK, 35-72.

Thoning, K. W., Tans, P. P. and Komhyr, W. D. 1989. Atmospheric carbon dioxide at Mauna Loa observatory, 2, Analysis of the NOAA/CMDL data, 1974-1985. J. Geophys. Res. 94, 8549-8565.

Yakir, D. and Wang, X.-F. 1996. Fluxes of $\mathrm{CO}_{2}$ and water between terrestrial vegetation and the atmosphere estimated from isotope measurements. Nature 380, 515-517.

Yakir, D. and Sternberg, L. 2000. The use of stable isotopes to study ecosystem gas exchange. Oecologia 123, 297311. 